\title{
ALBERTA's APPROACH TO LOCAL GOVERNANCE IN OIL AND GAS DEVELOPMENT
}

\author{
NiCKIE VLAVIANOS* AND CHIDINMA THOMPSON ${ }^{* *}$
}

This article reviews the legal role of Alberta municipalities in the regulatory regime that governs all stages of oil and gas development within the province. Specifically, it seeks to address how municipalities are involved in the decision-making processes preceding oil and gas development approval; how their views and concerns are addressed; and what steps they are able to take in an effort to regulate and manage development within their borders. It highlights the fact that Alberta's approach to governance in oil and gas development is one that, as a matter of law and policy, grants municipalities a limited role. Nonetheless, it argues that avenues exist that municipalities can, and have, pursued in an effort to adequately address local impacts and concerns surrounding development.
Cet article examine le rôle juridique des municipalités albertaines dans le régime de réglementation régissant les étapes du développement pétrolier et gazier dans la province. L'auteur cherche tout spécialement à aborder la manière dont les municipalités sont impliquées dans la prise de décision menant à l'approbation du développement pétrolier et gazier, c'est-à-dire de quelle manière leurs points de vue et préoccupations sont abordés ainsi que les mesures qu'elles peuvent prendre afin de réguler et gérer le développement au sein de leurs limites territoriales. L'auteur souligne le fait que l'approche albertaine à la gouvernance du développement pétrolier et gazier en est une qui en ce qui concerne le droit et la politique, accorde un rôle limité aux municipalités. Cependant, il faut valoir qu'il existe des possibilités permettant aux municipalités, comme elles l'ont déjà fait, de poursuivre l'effort d'aborder, comme il se doit, les préoccupations et l'impact local relatifs à l'environnement.

\section{TABLE OF CONTENTS}

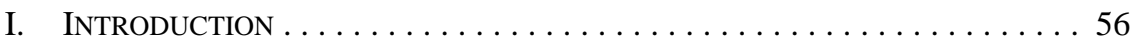

II. WHO ARE MUNICIPALITIES AND WHY ARE

THEy INTERESTED IN OIL AND GAS DEVELOPMENT? . . . . . . . . . . . . . . 59

A. Concerns About Oil and Gas Development $\ldots \ldots \ldots \ldots$. . . . . 61

III. The Role of Alberta Municipalities IN THE CURRENT

OIL AND GAs DEVELOPMENT FRAMEWORK . . . . . . . . . . . . . . . . . . 64

A. The Energy Policy and Land Use Planning Processes . . . . . 64

B. The Disposition Of OIL AND Gas RightS AND

THE ACQUisition OF LAND SURFACE RigHTS . . . . . . . . . . . . 67

C. Oil and Gas Project Approvals . . . . . . . . . . . . . . . 71

IV. THE REgUlation OF OIL AND GAS DEVELOPMENT

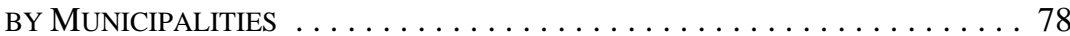

A. PART 17 OF THE MUNICIPAL GOVERNMENT ACT -

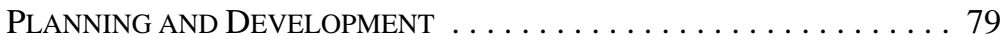

B. PART 2 OF THE MUNICIPAL GOVERNMENT ACT -

GENERAL BYLAW-MAKING POWERS . . . . . . . . . . . . . . . 85

Assistant Professor, Faculty of Law, University of Calgary; Research Associate, Canadian Institute of Resources Law, University of Calgary. Thanks to the Alberta Law Foundation for the generous funding that made this article possible, and to Adam Zelmer, Jenette Poschwatta, and Teshager Dasne for their research assistance. Thanks also to Arlene Kwasniak, as well as the three expert reviewers of this article, for their helpful comments.

*** LL.B, LL.M, Ph.D. Candidate, Faculty of Law, University of Calgary. Chidinma provided research assistance for this article. 


\section{CAse Study: Municipal Regulation With \\ RESPECT TO FLARING, NOISE, AND SETBACKS . . . . . . . . . . . . . . 87}

V. CONCLUSION ............................... 91

\section{INTRODUCTION}

As “creatures” of the provinces, little legal attention is typically paid to local governments or municipalities in Canada. ${ }^{1}$ This is especially true in Alberta in the context of oil and gas development, the backbone of the province's economy. Most accounts of the regulatory regime scarcely mention municipalities. Where they do, references are brief, reminding the reader that perhaps local governments need to be given notice of a pending project or that local permits might be required. ${ }^{2}$ What is clear is that municipalities are not key decisionmakers in whether and how oil and gas development proceeds in the province.

There are good reasons for centralized decision-making in the oil and gas context. Where, as in Alberta, resources are mostly publicly owned, there is a collective provincial interest in their management as well as a legitimate claim on the part of all Albertans to share in the benefits of their development. ${ }^{3}$ Centralization also ensures a level playing field for industry no matter where operations are located. It ensures consistency and predictability, at least with respect to minimum standards, and thus prevents the creation of a patchwork of regulations across the province which could lead to forum shopping by industry and a lowering of standards by municipalities to attract development for short-term benefit. Conversely, centralized decision-making guarantees that local concerns do not prevail over the concerns of the greater whole. Allowing all decisions to be subject to a local veto could promote a "not in my backyard" phenomenon that could undermine the well-being of the whole province in the interests of a few.

Still, there are downsides to centralized decision-making in energy development. It may be that the greater interest does not always equate with the local interest. While local communities do enjoy some economic benefits of development, they may also be disproportionately exposed to the negative impacts. Those impacts are often felt most acutely by local landowners and other individuals who use the land where the development is

1 The unfortunate "creature" label stems from the fact that municipalities are not a level of government recognized directly in Canada’s Constitution. They are created by provincial governments and can exercise only those powers conferred upon them by provincial statute: see R. v. Greenbaum, [1993] 1 S.C.R. 674. See also Eugene Meehan, Robert Chiarelli \& Marie-France Major, "The Constitutional Legal Status of Municipalities 1849-2004: Success Is a Journey, but Also a Destination” (2007) 22 N.J.C.L. 1.

2 See e.g. ERCB, Directive 056: Energy Development Applications and Schedules (Calgary: ERCB, 2008) [Directive 056]; ERCB, Directive 071: Emergency Preparedness and Response Requirements for the Petroleum Industry (Calgary: ERCB, 2008) [Directive 071]. All ERCB documents can be found online: ERCB <http://www.ercb.ca/portal/server.pt?>.

3 The Province of Alberta owns about 81 percent of the oil and gas located within the province: see Government of Alberta, “Our Business,” online: Alberta Energy <http://www.energy.gov.ab.ca/Our Business.asp>. 
occurring. In some cases, the impacts of development may be borne primarily by the local constituency, while the benefits flow elsewhere. ${ }^{4}$

Because municipalities are the natural vehicle for representing the values and interests of their local constituency, they are often on the frontlines in dealing with landowner discontent. Local governments are also often better positioned in terms of local knowledge to anticipate and deal with the social, economic, and environmental impacts of development. The Supreme Court of Canada has acknowledged that local governments are the level of government "closest to the citizens affected and thus most responsive to their needs, to local distinctiveness, and to population diversity." 5

Recent events in Alberta indicate that municipalities are increasingly testing their authority and ability to be more proactive in regard to oil and gas development within their borders. ${ }^{6}$ In numerous instances between 2005 and 2009, municipalities across the province opposed applications for licences to drill oil and gas wells or construct pipelines within their boundaries. $^{7}$ The concerns raised related to socio-economic and environmental impacts, public health and safety, emergency response, land use, municipal infrastructure and services, and property tax impacts. In the context of oil sands development, in 2006 and 2007 the Regional Municipality of Wood Buffalo (RMWB) intervened in three consecutive applications asking for future oil sands project approvals to be delayed until municipal services and infrastructure could catch up to address the increasing socio-economic impacts from rapid development in the region. ${ }^{8}$

See e.g. Sumas Energy 2, Inc.: Application dated 7 July 1999, amended 23 October 2000, for the Construction and Operation of an International Power Line, NEB Decision EH-1-2000 (March 2004), online: NEB <http://www.neb-one.gc.ca/ll-eng/livelink.exe?func=ll\&objld=313822\&objAction=browse \&sort=name $>$. While it is true that owners of land involved in development receive some compensation, this is not the case for nearby landowners and other residents or users.

114957 Canada Ltée (Spraytech, Société d'arrosage) v. Hudson (Town of), 2001 SCC 40, [2001] 2 S.C.R. 241 at para. 3 [Spraytech].

6 Historically, Alberta municipalities have, for a number of reasons, been largely conciliatory towards oil and gas development. In a 2003 report, for example, the City of Calgary concluded that "[f]or the most part, the position of the [City] has been to recognize the importance of recovering the valuable nonrenewable Provincial resource and to ensure the City's growth plans do not compromise the extraction of this resource": Ted Brown, An Overview of Initiatives Taken in the Calgary Area to Coordinate the Recovery of Sour Gas Reserves with Surface Development (Calgary: ERCB, 2003) at 3.1.2, online: ERCB <http://www.ercb.ca/docs/public/sourgas/PSSGRec5-OverviewofInitiatives.pdf $>$. See West Energy Ltd.: Application for a Well Licence - Pembina Field, ERCB Decision 2009-025 (3 March 2009) [West Energy 2009-025]; Bearspaw Petroleum Ltd.: Application for Two Wells and Two Pipeline Licences - Crossfield Field, ERCB Decision 2009-023 Errata (17 February 2009); Highpine Energy Ltd.: Application for Six Well Licences - Pembina Field, ERCB Decision 2008-088 (30 September 2008) [Highpine Energy]; Petro-Canada: Prehearing Meeting Applications for Wells and Associated Pipeline and Facility Licences — Sullivan Field, ERCB Decision 2008-029 (16 April 2008) [Petro-Canada]; Canadian Natural Resources Ltd.: Application for a Pipeline Licence - Taber Field, EUB Decision 2008-012 (12 February 2008); West Energy Ltd.: Applications for Well Licences Pembina Field, EUB Decision 2007-061 (8 August 2007); Decision on Requests for Consideration of Standing Respecting a Well Licence: Application by Compton Petroleum Corporation —Eastern Slopes Area, EUB Decision 2006-052 (8 June 2006) [Compton: Eastern Slopes]; West Energy Ltd.: Prehearing Meeting, Applications for Two Well Licences - Pembina Field, EUB Decision 2006-116 (21 November 2006) [West Energy 2006-116]; Compton Petroleum Corporation: Applications for Licences to Drill Six Critical Sour Natural Gas Wells, Reduced Emergency Planning Zone, Special Well Spacing, and Production Facilities - Okotoks Field (Southeast Calgary Area), EUB Decision 2005-060 (22 June 2005) [Compton: Okotoks].

8 Suncor Energy Inc.: Application for Expansion of an Oil Sands Mine (North Steepbank Mine Extension) and a Bitumen Upgrading Facility (Voyageur Upgrader) in the Fort McMurray Area, EUB Decision 2006-112 (14 November 2006); Albian Sands Energy Inc.: Application to Expand the Oil Sands Mining and Processing Plant Facilities at the Muskeg River Mine, Joint Panel Report, EUB Decision 2006-128 (17 December 2006); Imperial Oil Resources Ventures Ltd.: Application for an Oil Sands Mine and Bitumen Processing Facility (Kearl Oil Sands Project) in the Fort McMurray Area, Joint Panel Report, 
Alberta municipalities have also been considering their role outside of the regulatory approval process. In 2006, the City of Edmonton commissioned a report to study and make recommendations for how it could better manage the challenges it faces from increasing oil and gas development in and around the city. ${ }^{9}$ In 2003, Strathcona County created an energy exploration committee to make recommendations for how oil and gas development should proceed within the county. ${ }^{10}$ The County developed a protocol that it asks the oil and gas industry to follow. The protocol's stated purpose is to have oil and gas exploration and production occur "with the least possible impact on the environment, health, safety, and quality of life for the residents of the community." "It adds to the Energy Resources Conservation Board (ERCB) public notification and consultation requirements and asks operators to comply with the County's standards for flaring and venting, wildlife protection, environmental protection and reclamation, noise and light pollution, and emergency preparedness. $^{12}$

This article considers the legal situation of Alberta municipalities with respect to oil and gas development. Specifically, it asks the following questions: (1) how are municipalities involved in decision-making processes around oil and gas development in Alberta?; (2) how are their views and concerns taken into account?; (3) what can municipalities do in terms of regulating and managing oil and gas development within their borders?; and (4) what can they not do?

The balance of this article proceeds as follows. Part II describes the nature and mandate of municipalities in Alberta and outlines some of their concerns in regard to oil and gas development. Part III reviews some of the key stages in Alberta's oil and gas development framework and asks what role municipalities play in the current framework. It considers the policy-making stage, including the recent Land Use Framework process, the oil and gas rights disposition stage, the surface rights disposition stage, and the project approval stage.

EUB Decision 2007-013 (27 February 2007).

RMC \& Associates and Gecko Management Consultants, City of Edmonton: Oil and Gas Facilities Policy Review Project, Discussion Paper (8 February 2007) [unpublished, archived at City of Edmonton, Planning and Development Department]. See also City of Edmonton, Oil and Gas Facilities Policy Review, Implementation Plan (Edmonton: Planning and Development Department, 2008), online: City of Edmonton <http://www.edmonton.ca/city_government/documents/InfraPlan/Final_Implementation_ Plan.pdf $>$.

10 Strathcona County, News Release, “Energy Exploration Committee Established” (October 2003). See also Strathcona County, Bylaw No. 54-2009, Strathcona County Boards and Committees Bylaw (6 October 2009), online: Strathcona County <http://www.strathcona.ab.ca/files/files/att-lls-bylaw-542009.pdf>.

11 Strathcona County, The Strathcona County Protocol for Seismic Surveying, Drilling, Construction and Operation of Oil and Gas Facilities in Strathcona County (Sherwood Park: Strathcona County Engineering and Environmental Planning Department, 2008) at 1, online: Strathcona County <http:// www.strathcona.ab.ca/files/Attachment-EEP-Nov2008-Protocol.pdf $>$ [Strathcona Protocol].

12 Ibid. The Strathcona Protocol, which fails to set out any penalties for non-compliance, is not without critics: see D. Clark, "Strathcona Protocol ineffective: resident," Sherwood Park News (2008), online: Sherwood Park News <http://www.sherwoodparknews.com/ArticleDisplay.aspx?archive=true\&e= $1880410>$. In 2008, Parkland County, another municipality in Alberta, went further than Strathcona County and passed a bylaw requiring its review and approval of industrial activity emergency response plans: Parkland County, Bylaw No. 60-2008, Industrial Activity Emergency Response Plan Review and Approval Bylaw (9 December 2008). Provincial agencies immediately raised questions about overlapping regulation and duplication. As a measure of "good faith and commitment by all parties to go forward and improve existing processes to address the County's concerns, Parkland County acted on the recommendation that it ... rescind Bylaw 60-2008.” It did so on 6 June 2009: see Parkland County, News Release, "Parkland County rescinds bylaw, works with ERCB and other government agencies to resolve concerns” (8 July 2009) at 4. See also Parkland County, Bylaw No. 27-2009, a bylaw to rescind the Industrial Activity Emergency Response Plan Review and Approval Bylaw 60-2008 (6 June 2009). 
Part IV explores the possibility of municipalities directly regulating some aspects of oil and gas activities within their borders. This requires an examination of several provisions of Alberta's Municipal Government Act $^{13}$ as well as an analysis of recent case law on the resolution of conflicts between provincial legislation and municipal bylaws.

Part V summarizes the findings of this article and provides some concluding remarks. It highlights the fact that Alberta's approach to local governance in oil and gas development is one that, as a matter of law and policy, grants municipalities a minor role. ${ }^{14}$ This is true with respect to the setting of provincial energy and land use policy as well as decisionmaking around the disposition of provincially owned oil and gas rights and the granting of surface access to public lands. With respect to oil and gas project approvals, municipalities are simply like any other intervener. This is so despite their legislative mandates and local government status. If municipal land is not directly affected by a particular application, municipalities face significant barriers to effective participation in the project approval process. Likewise, this article concludes that municipalities face many roadblocks in their ability to regulate oil and gas development within their borders directly. Nonetheless, there are still windows of opportunity to be pursued. In so doing, municipalities may be able to ensure that at least some of the local impacts and concerns with respect to oil and gas development are adequately addressed.

\section{WHO ARE MUNICIPALITIES AND WHY ARE THEY INTERESTED IN OIL AND GAS DEVELOPMENT?}

Richard and Susan Tindal define a municipality as "a corporation, a legal device that allows residents of a specific geographic area to provide services that are of common interest," but also as a "democratic institution, governed by an elected council that exists as a vehicle through which local citizens can identify and address their collective concerns."15 For the Tindals, the raison d'être of municipalities is to provide a mechanism for inhabitants of defined local areas to express, debate, and resolve local issues and concerns. Municipal governments provide an opportunity to choose representatives who will make decisions that reflect, or at least respond to, the views and concerns of local citizens. In their view, "[t]he municipality is an extension of the community, the community governing itself." 16 Similarly, courts have recognized the role of municipal councils in "reflect[ing] the conscience of the community." ${ }^{\text {"17 }}$

Municipalities provide a wide range of services, facilities, and regulations that affect our day-to-day lives. In Canada, local governments generally exercise responsibility in the following areas: "policing; fire protection; animal control; roads ... parking; public transit; water supply (and sometimes natural gas, electricity, and telephones); sewage collection and treatment; solid-waste collection and disposal; land-use planning and regulation; building

R.S.A. 2000, c. M-26 [MGA].

While the practical experiences of municipalities across the province may vary, the focus throughout this article is the position of Alberta municipalities in terms of current law and policy.

C. Richard Tindal \& Susan Nobes Tindal, Local Government in Canada, 6th ed. (Toronto: Nelson, 2004) at 2.

Ibid. at 6 [footnotes omitted]. See also Ian Rogers, The Law of Canadian Municipal Corporations, 2d ed., looseleaf (Toronto: Carswell, 2009) vol. 1, c. 1.

Smith v. White City (Village of) (1989), 81 Sask. R. 79 at para. 5 (Q.B.). 
regulation and inspection; economic development and promotion; public libraries; parks and recreation; cultural facilities...; business licensing; and emergency planning." ${ }^{18}$ In addition, municipalities have varying responsibilities over public education, health, and welfare at the local level. ${ }^{19}$

Alberta's municipalities are created and empowered by the MGA. Section 1(1)(s) defines a "municipality" as "a city, town, village, summer village, municipal district or specialized municipality,” or, if the context requires, as its geographical area. The terms "local authority," "local government," and “municipal authority” are typically used interchangeably with "municipality."20 There are 356 municipalities in Alberta: 278 urban ones (that is, cities, towns, villages, and summer villages), four specialized ones, and 74 rural municipalities (including municipal districts). ${ }^{21}$

Section 3 of the MGA sets out the purposes of Alberta municipalities as follows: "(a) to provide good government, (b) to provide services, facilities or other things that, in the opinion of council, are necessary or desirable for all or a part of the municipality, and (c) to develop and maintain safe and viable communities.”22 All powers granted to municipalities by the MGA must be exercised in accordance with these purposes.

The MGA grants municipalities the ability to enact bylaws respecting a variety of matters including: (a) "the safety, health and welfare of people and the protection of people and property"; (b) "nuisances, including unsightly property"; (c) "transport and transportation systems"; (d) business and business activities; (e) "services provided by or on behalf of the municipality”; and (f) public utilities. ${ }^{23}$ According to s. 9(b), these general bylaw-making powers are to be construed broadly so as to "enhance the ability of councils to respond to present and future issues in their municipalities." ${ }^{24}$ Increasingly, case law is exposing the ability of municipalities to protect the environment through such general bylaw-making powers, especially in regard to public health and safety. ${ }^{25}$

Undoubtedly, a critical power granted to Alberta municipalities is the ability to control and regulate the use and development of all private and municipal land within their boundaries, as well as public land in some cases. ${ }^{26}$ Municipalities are empowered to (and in some cases

\footnotetext{
18 Andrew Sancton, "Provincial and Local Public Administration” in Christopher Dunn, ed., The Handbook of Canadian Public Administration (Don Mills, Ont.: Oxford University Press, 2002) 249 at 254. Ibid.

Supra note 13.

Government of Alberta, Understanding Land Use in Alberta (Edmonton: Alberta Sustainable Resource Development, 2007) at 25, online: Alberta Sustainable Resource Development $<$ http://landuse.alberta. ca/AboutLanduseFramework/LUFProgress/documents/UnderstandingLandUseinAlberta-Apr2007.pdf> [Understanding Land Use].

Supra note 13.

Ibid., s. 7.

Ibid..

See e.g. Spraytech, supra note 5 at para. 20; Croplife Canada v. Toronto (City of) (2005), 75 O.R. (3d) 357 (C.A.) [Croplife].

See MGA, supra note 13, Part 17. Because the MGA does not bind the Crown, municipal planning documents and bylaws do not apply to provincially owned (Crown) lands in Alberta as long as those lands are being used by the Crown. However, where Crown land has been leased to a private company (for oil and gas development, for example), Part 17 of the MGA will apply unless the Crown has claimed immunity in the lease contract or in some other way: see Frederick A. Laux, Planning Law and Practice in Alberta, 3d ed., looseleaf (Edmonton: Juriliber, 2005) at §§ 4.1(5)(b)-(c); Squamish (District of) v. Great Pacific Pumice Inc., 2000 BCCA 328, 187 D.L.R. (4th) 483, leave to appeal to S.C.C. refused, (2001), 267 N.R. 200 (note).
} 
must) adopt several documents as tools for land use planning. These include municipal development plans, area structure plans, area redevelopment plans, and land use bylaws. These documents set out a municipality's goals and objectives for present and future land use and, in the case of the land use bylaw, assist approving authorities (such as development and subdivision authorities, planning commissions, and appeal boards) to make decisions on proposals to designate, subdivide, or develop land. ${ }^{27}$ Section 617 sets out the purpose of the planning and development provisions in the $M G A$ as providing the means whereby plans and related matters may be prepared and adopted so as "to achieve the orderly, economical and beneficial development, use of land and patterns of human settlement" and "to maintain and improve the quality of the physical environment within which patterns of human settlement are situated in Alberta” to the extent necessary for the overall public interest. ${ }^{28}$

The MGA also imposes several other areas of responsibility on municipalities. These include the control and management of roads and water bodies within the municipality, the authority to expropriate and annex land, and the raising of revenues through property, business, and other taxation. ${ }^{29}$ Municipalities are also responsible for responding to emergencies within their borders. Pursuant to Alberta's Emergency Management Act, ${ }^{30}$ municipalities have primary responsibility for declaring a local state of emergency for all or part of a municipality. ${ }^{31}$ Although Cabinet may also declare a state of emergency, it may "require a local authority to put into effect an emergency plan or program for the municipality." 32 Section 11 of the EMA emphasizes that municipalities "shall, at all times, be responsible for the direction and control of the local authority's emergency response unless the Government assumes direction and control.” In the oil and gas context, the ERCB has often noted the responsibility of municipalities "for the protection of the public within [their] area of jurisdiction" and their duty to respond "regardless of the type of emergency."33

\section{A. CONCERNS ABout OIL AND GAS DEVElopment}

There are several reasons why municipalities may be interested in the course of oil and gas development within their borders. Municipalities may be interested because of the economic benefits that come from development in the form of increased revenue from municipal taxation, fees, and the boost to the local economy generally. With respect to impacts, the concerns relate to municipalities' mandates to ensure the protection of the health, safety, and quality of life of residents as well as to ensure their ability to carry out their responsibilities in terms of roads, infrastructure, social services, etc. that will be impacted by oil and gas development. As noted by one commentator, although "mineral development has historically been a favored use of land, local governments are more

27 The land use bylaw is the key regulatory tool that regulates and controls the use of land in a municipality in Alberta. It divides the municipality into districts or "zones" (e.g. industrial, residential, commercial, and agricultural) and must state what uses are permitted, and what uses are discretionary for each district: see MGA, ibid., Part 17, Division 5. See also Laux, ibid.

MGA, ibid.

Ibid., ss. 14-15, 16-27.6, 60, 112.1-128, 326-484.1.

R.S.A. 2000, c. E-6.8 [EMA].

Ibid., s. 21. An "emergency" is defined as an event requiring "prompt co-ordination of action or special regulation of persons or property to protect the safety, health or welfare of people or to limit damage to property" (s. 1(f)).

Ibid., ss. 18(1), 19(1)(b).

See e.g. Canadian 88 Energy Corp.: Application to Drill a Level 4 Critical Sour Gas Well in the Lochend Field, EUB Decision 99-16 (7 July 1999) [Canadian 88]. 
interested than ever before in deciding for the mineral owner where, when, or whether such development will happen within their jurisdictions." 34

Oil and gas operations undoubtedly have major implications for public safety and quality of life, for land use, and for municipal infrastructure and services. In recently adopting an oil and gas policy and procedure, the City of Edmonton outlined its desire to "ensure the orderly and safe co-existence of urban development and oil and gas facilities within the City of Edmonton" according to a number of principles. ${ }^{35}$ These principles clearly summarize Edmonton's concerns and are indicative of the concerns of other municipalities as well. They are: (a) ensuring the safety of the public, including the minimization and prevention of risks to citizens' health and well-being; (b) enabling the citizens of Edmonton to enjoy the best possible quality of life (social, health, economic, and environmental); (c) minimizing and managing nuisances from oil and gas activities ("including noise, odours, dust, glare, traffic and aesthetic concerns"); (d) ensuring that oil and gas activity does not negatively affect the City's ability to undertake urban development; (e) ensuring that the City's environmental policies (for example, the prevention of pollution) are achieved in conjunction with oil and gas development; (f) ensuring that the development of city infrastructure and oil and gas resources is balanced with protecting health, safety, and the interests of citizens; and (g) ensuring that the City carries out its legislative mandates with respect to municipal development. $^{36}$

A number of factors have likely contributed to the increased interest of municipalities in oil and gas development in recent years. Despite a very recent drop in activity in the past year or so due to changed economic circumstances, prior years had seen an intense pace of conventional and unconventional (for example, coal bed methane and oil sands) oil and gas activity in the province. This was coupled with a significant increase in the province's population. In the 2007 report commissioned by the City of Edmonton, the authors summarized the situation at the time:

The global increase in demand for petroleum products, the recent increase in crude oil prices, and the rise in extraction technology have all served to increase the volume of oil and gas activity in and around Edmonton. At the same time, there has been a rapid increase in the [City of Edmonton's] population, which has resulted in widespread urban growth.

The expansion of Edmonton's city boundaries into areas with a significant volume of existing oil and gas activity combined with an influx of new oil and gas activity in or near Edmonton has led to increased conflicts over land use. The research undertaken as part of this study has indicated that [Edmonton] is not alone in facing these land use issues. A number of municipalities across Alberta are struggling with similar challenges around managing the co-existence of sub-surface mineral resource extraction with the need to develop surface land for urban and residential uses. ${ }^{37}$

Christopher G. Hayes, “Access to Oil, Gas, and Other Minerals in Urban Areas” in Annual Institute Proceedings, vol. 53 (Boulder, Colo.: Rocky Mountain Mineral Law Institute, 2007) at 6-2. City of Edmonton, City Policy: Oil and Gas Facilities, Policy Number C515 (Edmonton: Planning and Development Department, 2007) at 1, online: City of Edmonton <http://www.edmonton.ca/city_ government/documents/City_Policy_Oil_and_Gas.pdf>.

Ibid. at 1-2. For examples of municipalities raising such concerns to the ERCB, see the decisions cited at supra notes 7-8.

RMC \& Associates and Gecko Management Consultants, supra note 9 at 9. 
Similarly, the Alberta government stated that

[i]n some areas, residential expansion of cities, towns or acreage subdivisions is occurring on the land above existing oil and gas fields, coal and gravel deposits, or other subsurface resources. In other places, previously undetected oil and gas fields are being identified beneath existing urban and residential sites or new energy projects are being developed within expected growth areas. Accessing these resources increases the potential for conflict between industry, landowners and the public. ${ }^{38}$

Along with land use impacts, Alberta municipalities are also increasingly being asked to respond to their constituents' concerns about the environmental and public health risks of oil and gas development. These include not only the risks and impacts associated with the drilling and operation of active facilities, but also the legacy associated with abandoned installations, which can inhibit future development and pose ongoing and indefinite risks. As the most accessible level of government, it is logical that Albertans would turn first to their municipality to have their concerns addressed. ${ }^{39}$

Municipalities are also interested in oil and gas development because they want to ensure that they have the ability to carry out their responsibilities in terms of providing local infrastructure, social services, etc. As noted by Christopher Hayes:

[A]n oil and gas development boom may spur secondary development as people move to the area to work in the newly created industry. In addition, it is often asserted that the increased truck traffic that accompanies an oil and gas development boom cause local infrastructure to wear out faster than planned. Local government tax assessments, collections, or both may fail to keep up with the pace of development, leaving the government unable to provide the necessary expansions of roads, sewers, schools, emergency response and other services that citizens expect. ${ }^{40}$

Undoubtedly the best recent example of a strained municipality in Alberta is the RMWB, which has had to deal with significant secondary development associated with an oil sands development boom. ${ }^{41}$

With respect to emergency response, Alberta municipalities are, as noted, key responders to emergencies emanating from oil and gas activities. In the event of a spill or other emergency situation, “[a]lthough the facility operator will most likely initiate the emergency response, the local municipal authority will take a lead role in matters affecting public safety

$38 \quad$ Understanding Land Use, supra note 21 at 24.

39 As elsewhere, environmental consciousness amongst Albertans continues to rise, leading naturally to increasing concerns about the health and quality of life impacts of oil and gas development in the province: see e.g. Alberta Energy and Utilities Board, Battle Lake Watershed Development Planning Pilot Project: Report of the Multistakeholder Pilot Project Team (Calgary: Alberta Energy and Utilities Board, 2006) at 3, where it is stated that residents "want to be protected from deterioration of their quality of life that can result from noise, odours, air emissions, traffic dust, nighttime light and aesthetic effects of upstream oil and gas operations in the Battle Lake watershed.” See also Nickie Vlavianos, Albertans' Concerns about Health Impacts and Oil and Gas Development: A Summary, Human Rights Paper \#3 (Calgary: Canadian Institute of Resources Law, 2006); Tom Marr-Laing \& Chris SeversonBaker, Beyond Eco-terrorism: The Deeper Issues Affecting Alberta’s Oilpatch (Drayton Valley: Pembina Institute for Appropriate Development, 1999).

40 Supra note 34 at 6-10-6-11 [footnotes omitted].

41 See supra note 8 and accompanying text. 
within its jurisdiction." ${ }^{42}$ This mandate means municipalities will have a keen interest in the type and intensity of oil and gas development that occurs within its borders.

\section{The Role OF Alberta Municipalities IN THE CURRENT OIL AND GAS DEVELOPMENT FRAMEWORK}

As noted, there are several reasons why Alberta municipalities may be interested in the nature, extent, location, and ongoing operations of oil and gas development within their borders. This Part considers their role in the current oil and gas development decisionmaking framework. It asks whether, and how, municipalities are involved and what opportunities they have to ensure that their concerns are taken into account.

This Part focuses on the key stages in Alberta's current oil and gas development framework. The first stage relates to the formation of provincial energy policy and land use planning. Such policy and land use planning should guide subsequent stages in the development process. The second stage concerns the disposition of rights to explore for and develop the province's oil and gas resources. Third, once acquired, a company must obtain land surface access rights to exercise its rights to explore and develop oil and gas resources. The fourth stage is that of individual oil and gas project reviews and approvals. Last, there is the post-approval stage; that of operations and, ultimately, the abandonment and decommissioning of facilities and reclamation of the site impacted. For each stage, this Part focuses on the role of municipalities. It considers whether and how the views of municipalities are taken into account at each stage and what, if any, their jurisdiction is to influence each stage in the process from a legal point of view.

\section{A. Energy Policy and land Use Planning Processes}

Ideally, decision-making around oil and gas development in Alberta should fit within, and be driven by, an overall resource and environmental management policy and land use planning structure. Among other things, such policies and plans would assist with individual project decision-making.

\section{Provincial ENERGy STRATEgY}

Recently, the Alberta government has taken steps towards developing a comprehensive energy policy and land use planning framework for the province. Previous government policies were criticized for being inconsistent, lacking in specifics, and prioritizing development over environmental protection. ${ }^{43}$ Alberta's current energy strategy, which Public Health and Safety: Roles and Responsibilities of Agencies that Regulate Upstream Oil and Gas (Calgary: ERCB, 2009) at 3, online: ERCB <http://www.ercb.ca/docs/public/EnerFAQs/PDF/Ener FAQs10-Public Health.pdf> [EnerFAQs].

43 See e.g. Michael M. Wenig \& William A. Ross, "Making progress toward a truly integrated energy policy” LawNow 31:4 (March/April 2007) 43; Andrew Nikiforuk, "Plan? What Plan? Alberta’s Energy Future” Canadian Business 79:12 (5 June 2006) 41; Elona Malterre \& Mark Lowey, “Alberta’s New Energy Vision Faces Huge Challenges” EnviroLine 16:19-20 (July 2006) 1; Michael M. Wenig, "Federal Policy and Alberta's Oil and Gas: The Challenge of Biodiversity Conservation” in G. Bruce Doern, ed., How Ottawa Spends, 2004-2005: Mandate Change in the Martin Era (Montreal: McGillQueen’s University Press, 2004) 222. 
provides the context for oil and gas development in the province, states its vision to be that of ensuring Alberta remains a global energy leader through the continued development of fossil fuels. ${ }^{44}$ This vision will be met by achieving three goals: "clean energy production, wise energy use, and sustained economic prosperity." 45 These goals will be achieved by (1) addressing the environmental footprint of energy; (2) investigating and exploring ways to add value to Alberta's energy industry; (3) changing energy consumption behaviour; (4) improving innovation with regard to energy technology, leadership, and development of people; (5) enhancing the capability of Alberta's electricity system; (6) bolstering knowledge and awareness of, and appropriate education on, energy issues; and (7) aligning the energy strategy with other initiatives, programs, policies, and regulations. ${ }^{46}$

The energy strategy does not provide a role for municipalities in the development of policy or actions to meet these goals, nor does it require consultation with municipalities to be impacted by oil and gas development. ${ }^{47}$ Although in practice there have been examples of the Alberta government partnering with municipalities on an ad hoc basis to respond to socio-economic pressures, there is no indication that municipalities are, or will be involved in the initial policy stage that ultimately determines the course of oil and gas development in the province. There is also no evidence that municipalities were in any way consulted on the formation of the current energy strategy. ${ }^{48}$

\section{LAND USE FRAMEWORK}

Along with policies to guide oil and gas development in Alberta, commentators have called upon the government to adopt a comprehensive land use planning framework for years. ${ }^{49}$ The Alberta government has finally responded. ${ }^{50}$ In 2008, it released a policy document called the Land-use Framework outlining its approach to managing public and

Government of Alberta, Launching Alberta's Energy Future: Provincial Energy Strategy (Edmonton: Alberta Energy, 2008), online: Alberta Energy < http://www.energy.alberta.ca/Org/pdfs/AB_Provincial EnergyStrategy.pdf $>$ [ Provincial Energy Strategy]. See also Michael M. Wenig \& Jenette Poschwatta, Developing a "Comprehensive Energy Strategy" with a Capital "C," Occasional Paper \#22 (Calgary: Canadian Institute of Resources Law, 2008).

45 Provincial Energy Strategy, ibid. at 2.

$46 \quad$ Ibid. at 21.

47 There is only one mention of municipalities in the Provincial Energy Strategy, ibid., as follows: that the province commits to encouraging municipalities to reduce urban sprawl and increase housing density to reduce energy consumption (at 39). Further, the only consultative commitment in the strategy is for the province to meet its legal duty to consult with Aboriginal communities whose constitutionally protected rights under s. 35 of the Constitution Act, 1982, being Schedule B to the Canada Act 1982 (U.K.), 1982, c. 11, are potentially adversely impacted by development (at 47).

48 An example of the Alberta government working with a municipality to address impacts of development is the Fort McMurray Community Development Plan: see Government of Alberta, Government of Alberta Strategic Business Plan (Edmonton: Alberta Finance and Enterprise, 2009) at 8, online: Alberta Finance and Enterprise <http://www.finance.alberta.ca/publications/budget/budget2009/govbp.pdf > . See also "Province of Alberta begins development of two new communities in Fort McMurray,” Daily Commercial News and Construction Record (25 June 2008), online: Daily Commercial News and Construction Record <http:// www.dailycommercialnews.com/article/id28574>.

49 See e.g. Steven A. Kennett et al., Managing Alberta's Energy Futures at the Landscape Scale, Paper No. 18 of the Alberta Energy Futures Project (Calgary: Institute of Sustainable Energy, Environment and Economy, University of Calgary, 2006); Steven A. Kennett, Integrated Landscape Management in Canada: Getting from Here to There, Occasional Paper \#17 (Calgary: Canadian Institute of Resources Law, 2006); Reg Lang, ed., Integrated Approaches to Resource Planning and Management (Calgary: University of Calgary Press, 1986).

50 The MGA, supra note 13, highlights the provincial government's authority to establish land use policies for the province as a whole (s. 622(1)). Municipal statutory plans, land use bylaws, and actions must comply with such land use policies (s. 622(3)). 
private lands and natural resources in the province. ${ }^{51}$ The Framework envisions the division of the province into seven new land use regions and the development of unique regional land use plans for each region. The plans will be universally binding and will provide the context for all land use decision-making in each region, including those relating to oil and gas development. $^{52}$

The Framework was translated into legislation by the Alberta Land Stewardship Act. ${ }^{53}$ ALSA empowers the provincial Cabinet to divide Alberta into different planning regions and allows Cabinet to create regional plans for each region. ${ }^{54}$ Cabinet is empowered (but not mandated) to establish Regional Advisory Councils (RACs) for each region in the province. If established, the RACs may provide their input to Cabinet in the development of the regional plans. ${ }^{55}$ Although the Framework states that the RACs will consist of members "representing a range of perspectives and experience in the region and who are able to appreciate the broad interest of the region and its place in the province," ${ }^{56}$ ALSA also does not set out any membership criteria or guidelines for the appointment of members of the RACs. ${ }^{57}$ Ultimately, Cabinet retains broad powers to create, amend, and implement regional plans; it may or may not implement recommendations from a RAC. ${ }^{58}$

Regional plans will be legally binding on everyone, including local governments. ${ }^{59}$ Municipalities will be required to make all future development and land use planning decisions in accordance with applicable regional plans. They must also review all existing regulatory instruments (including all bylaws and municipal planning documents) and decide what, if any, changes are required for compliance with a regional plan. ${ }^{60}$ Any existing regulatory instrument that conflicts with a regional plan will be superseded by the plan. ${ }^{61}$ Further, although the Framework states that the province will respect the existing land use planning and decision-making authority of municipalities, ALSA grants Cabinet the ability to make, as part of a regional plan, "law about matters in respect of which a local government body may enact a regulatory instrument.",62

Given the potential significance of regional plans on the local land use and planning jurisdiction of municipalities, several issues arise. First, there is no indication that municipalities were consulted in any direct way in the public consultation processes that led up to the government's adoption of the Framework and the drafting of ALSA. Rather, municipalities were entitled to provide their input as part of the general "public" consultation

Government of Alberta, Land-use Framework(Edmonton: Alberta Sustainable Resource Development, 2008), online: Alberta Sustainable Resource Development <http://www.landuse.alberta.ca/AboutLand useFramework/LUFProgress/documents/LanduseFramework-Final-Dec3-2008.pdf> [Framework]. Ibid. at 19.

S.A. 2009, c. A-26.8 [ALSA].

Ibid., s. 4(1).

Ibid., s. 51(1).

Framework, supra note 51 at 29.

ALSA, supra note 53, s. 52(1). For criticism of the broad discretion granted to Cabinet in appointing members of the RACs, see Environmental Law Centre, "Bill 36 - Limited Rights to Participate and Appeal” Backgrounder (1 May 2009), online: Environmental Law Centre <http://www.elc.ab.ca/ Content_Files/Files/Backgrounder_Limited_rights_to_participate_and_appeal.pdf $>$.

See ALSA, ibid., ss. 8(2), 9(1)-(2).

Ibid., s. 15(1).

Ibid., s. 20(1).

Ibid., s. 17(1)(b).

Ibid., s. 9(2)(f). 
process. ${ }^{63}$ Second, assuming RACs will indeed be struck for each region, ALSA contains no requirement for local government representation. This is especially surprising given the local knowledge that municipalities hold in terms of land use and planning within their respective jurisdictions. Consequently, there is no guarantee that municipalities will be represented on the RACs. Third, even if they are granted representation, the ability of Cabinet to adopt or reject the recommendations from the RACs means that the views and concerns of municipalities in terms of land use planning within their borders may not be adequately addressed in any regional plan. Lastly, the ability of Cabinet to usurp local land use planning jurisdiction by enacting laws in relation to municipal matters should be particularly worrisome for Alberta municipalities. ${ }^{64}$

\section{B. THE DisPosition OF OIL AND GAS RIGHTS AND THE ACQUISITION OF LAND SURFACE RIGHTS}

\section{OIL AND GAS RIGHTS}

As noted, approximately 81 percent of Alberta's oil and gas resources are owned by the Province of Alberta. These resources are located either underneath lands whose surface is owned privately or under provincially owned lands whose surface may be legally used or occupied by individuals, companies, or the general public. Alberta Energy disposes of the rights to produce the province's oil and gas resources pursuant to a tenure regime established under the Mines and Minerals $A c t^{65}$ and applicable regulations. ${ }^{66}$ Royalties, bonus bid payments, and rents are payable to the province in exchange for the rights to explore, drill, and capture hydrocarbon resources. ${ }^{67}$

Alberta's oil and gas rights are issued in the form of licences, permits, or leases through a "competitive sealed bid auction system" where the highest bidder is awarded the rights to drill for and recover the oil and gas. ${ }^{68}$ Public offerings are held every two weeks; notice of the parcels to be offered are published on Alberta Energy's website, and in paper copy, about eight weeks prior to the sale. ${ }^{69}$ Prior to a public offering, Alberta Energy forwards a description of the lands to be offered to the Crown Mineral Disposition Review Committee (CMDRC). The CMDRC is comprised of representatives from the Departments of Sustainable Resource Development, Environment, and Culture and Community Spirit, as

For the public consultation process undertaken, see Government of Alberta, "Land-use Framework," online: Alberta Sustainable Resource Development <http://www.landuse.alberta.ca/Default.aspx>. Interestingly, only 28 percent of Albertans surveyed about the Framework believed that it struck the right balance between provincial leadership and local decision-making. By contrast, 32 percent felt that there would be too much government involvement or that the Framework's structure would be too topdown or centralized: see Sierra Systems Group, Draft Land-use Framework: Public Survey and Public Submissions Report (N.p.: Sierra Systems Group, 2008), online: Alberta Sustainable Resource Development <http://www.landuse.alberta.ca/AboutLanduseFramework/LUFProgress/documents/Draft LUF-PublicSurveyPublicSubmissionReport-Nov2008.pdf $>$. R.S.A. 2000, c. M-17. See the Petroleum and Natural Gas Tenure Regulation, Alta. Reg. 263/97; Oil Sands Tenure Regulation, Alta. Reg. 50/2000; Mines and Minerals Administration Regulation, Alta. Reg. 262/97. Government of Alberta, “Tenure,” online: Alberta Energy <http://www.energy. alberta.ca/OurBusiness/ tenure.asp>.

68 Ibid. See also Government of Alberta, Alberta Oil Sands Tenure Guidelines: Principles and Procedures (14 August 2009), online: Alberta Energy <http://www.energy.alberta.ca/OilSands/809.asp> . 
well as from the ERCB and the Municipal Affairs Special Areas Board. ${ }^{70}$ The CMDRC reviews the lands involved and identifies any potential surface access restrictions that may be required by law or policy. For example, seasonal access restrictions designed to protect wildlife habitats should be identified and referred back to Alberta Energy, who then reviews the restrictions and determines whether the minerals are to be posted for sale and, if so, under what conditions. The CMDRC does not address surface issues pertaining to non-Crown owned (that is, private) lands. ${ }^{71}$

In recent years, commentators have questioned the lack of public consultation at the rights disposition stage, both for the public at large and for more directly affected groups, such as surface landowners and local governments, who will be left to deal with the socio-economic and infrastructure impacts of development. ${ }^{72}$ Given the potential for industry activity to have significant cumulative and long-term environmental impacts, it is argued that the views of Albertans should be heard at the rights disposition stage, which constitutes the critical first step in the oil and gas development process. ${ }^{73}$ Current legislation does not require Alberta Energy to consider the socio-economic and environmental impacts of future development when deciding whether to dispose of oil and gas rights, nor does Alberta Energy conduct any assessment of the impacts that will result from the activities undertaken to develop the rights that will be sold. ${ }^{74}$ There are no guidelines, factors, or purposes set out in the relevant legislation and regulations to guide Alberta Energy in its disposition decisions. The

Government of Alberta, “Crown Mineral Disposition Review Committee,” online: Alberta Sustainable Resource Development <http://www.srd.alberta.ca/ManagingPrograms/Lands/CrownMineralDisposition ReviewCommittee.aspx>. Elsewhere, it is stated that Alberta Municipal Affairs and Housing is a member: see Strathcona County, Energy Exploration Quarterly Report, Strathcona County Council Meeting (7 October 2008), online: Strathcona County <http://www.strathcona.ab.ca/departments/ Legislative_and_Legal_Services/Agendas_reports_minutes/Council-meeting-October-7-2008.aspx> [Strathcona County, Quarterly Report]. There is no Alberta government document confirming this, however. Generally, the lack of accessible documents about the CMDRC make it difficult to reach conclusions as to its mandate, membership, and decision-making processes: see Michael M. Wenig \& Michael S. Quinn, "Integrating the Alberta Oil and Gas Tenure Regime with Landscape Objectives: One Step Toward Managing Cumulative Effects” in H. Epp, ed., Access Management: Policy to Practice. Proceedings of the Conference Presented by the Alberta Society of Professional Biologists in Calgary, 18-19 March 2003 (Calgary: Alberta Society of Professional Biologists, 2004) 27.

71 Alberta Energy, Information Letter 2007-21, "Crown Mineral Rights; Identification of Major Surface Concerns in Public Offering Notices” (27 June 2007) at 2 [Information Letter 2007-21].

72 For Aboriginal peoples in Alberta, the duty to consult may raise unique considerations with respect to the lack of consultation at the time of mineral rights disposition. The argument was made recently, but not addressed by the Court, in Athabasca Chipewyan First Nation v. Alberta (Minister of Energy), 2009 ABQB 576, [2010] 2 W.W.R. 703. An appeal of this decision has been heard, and a decision from the Alberta Court of Appeal is pending. For comment on the trial decision, see Nigel Bankes, "The role of a limitations defence in a judicial review application involving the Crown's duty to consult” ABlawg (26 October 2009), online: The University of Calgary Faculty of Law Blog on Developments in Alberta Law <http://ablawg.ca/wp-content/uploads/2009/10/blog_nb_athabasca_abqb_oct2009.pdf>.

73 See e.g. Jody Hierlmeier, “B.C. Serves Notice: A novel approach sees landowners in the province’s energy heartland informed prior to resource development" Alberta Oil (1 December 2008), online: Alberta Oil <http://www.albertaoilmagazine.com/2008/12/bc-serves-notice/>; Robert R.G. Williams, "The Conflict Between the Oil and Gas Industry and Agricultural Landowners - the Major Issues and Some Legal Recommendations to Resolve It” News Brief 17:2 (2002) 6, online: Environmental Law Centre <http://www.elc.ab.ca/Content_Files/Files/NewsBriefs/Vol.17No.22002.pdf>; Steven A. Kennett \& Michael M. Wenig, “Alberta's Oil and Gas Boom Fuels Land-Use Conflicts - But Should the EUB Be Taking the Heat?” Resources 91 (Summer 2005) 1, online: Canadian Institute of Resources Law <http://dspace.ucalgary.ca/bitstream/1880/47049/1/Resources91.pdf>; Nickie Vlavianos, "Public Participation and the Disposition of Oil and Gas Rights in Alberta” (2007) 17 J. Envtl. L. \& Prac. 205; Nickie Vlavianos, The Legislative and Regulatory Framework for Oil Sands Development in Alberta: A Detailed Review and Analysis, Occasional Paper \#21 (Calgary: Canadian Institute of Resources Law, 2007) [Vlavianos, Oil Sands Development].

$74 \quad$ See Wenig \& Quinn, supra note 70; Steven A. Kennett \& Monique M. Ross, In Search of Public Land Law in Alberta, Occasional Paper \#5 (Calgary: Canadian Institute of Resources Law, 1998). 
legislation grants the Minister wide discretion to dispose of rights to develop the province's oil and gas resources without any guidance on how that discretion is to be exercised.

Although there are opportunities for public input, including input from affected local governments, after the disposition of oil and gas rights there are concerns that, by that stage, there is less opportunity to deal with important social, planning, and resource management issues. Because the disposition results in the purchase (typically for large sums of money) of property rights, it has been argued that "the granting of mineral rights creates a snowballing effect that leaves regulators like the [ERCB] hard pressed to adopt any kind of limitations that would effectively preclude the exercise of those rights." "75 All other factors being equal, the existence of property rights can tilt the Board's public interest calculation, discussed below, in favour of approving the project. $^{76}$

Currently, there is no required direct notice of any kind to local governments of the imminent sale of subsurface rights, nor is there any procedure for comment or consultation prior to the disposition. The CMDRC, which conducts the only review prior to a disposition, lacks direct representation on behalf of municipalities in the province ${ }^{77}$ and it does not appear to allow for concerns to be heard directly from potentially affected stakeholders. ${ }^{78}$ Further, the CMDRC's review is limited to broad environmental concerns that could affect surface access for development on Crown lands only. It does not consider the potential impacts of development on public health and safety, municipal services, and infrastructure, etc., nor does it consider impacts in relation to private lands. ${ }^{79}$

In short, municipalities are not consulted in the decision-making process for the sale of Crown-owned oil and gas rights. Municipalities are also not directly notified when oil and gas rights within their boundaries are being, or have been sold by the government. ${ }^{80}$ Although Alberta Energy recommends that prospective and current Crown mineral lessees consult with local governments on issues around surface access, there is no requirement for the province to do so prior to selling the rights, which will ultimately determine the pace and intensity of development within municipal borders. ${ }^{81}$

There is evidence that Alberta municipalities would like to be more involved in the rights disposition process. In 2008, members of Strathcona County’s Energy Exploration Committee met with representatives from Alberta Energy to discuss "mineral sales impacts

75 See Kennett \& Wenig, supra note 73 at 5. See also Michael M. Wenig, "Who Really Owns Alberta’s Natural Resources?” LawNow 28:3 (December 2003) 39.

Kennett \& Wenig, ibid.

The Municipal Affairs Special Areas Board provides municipal services to three special areas in the southeastern portion of the province: see Government of Alberta, "Special Areas Board,” online: Municipal Affairs <http://www.municipalaffairs.gov.ab.ca/am_special_areas_board.cfm>.

78 Williams, supra note 73.

79 See generally supra note 73. See also Provincial Advisory Committee on Public Safety and Sour Gas, Public Safety and Sour Gas: Findings and Recommendations Final Report (Calgary: Provincial Advisory Committee on Public Safety and Sour Gas, 2000) at 11, online: Public Safety and Sour Gas <http://www.publicsafetyandsourgas.org/FnlRprt.pdf $>$.

80 The usefulness of Alberta Energy's current notices of public offering for a non-industry audience has been questioned. The notices are highly technical and not user-friendly. They are also not readily searchable by surface land description: see Wenig \& Quinn, supra note 70.

81 See Information Letter 2007-21, supra note 71 at 2, where it is stated that prospective purchasers should fully assess opportunities for surface access, including consulting with relevant municipal governments, and incorporate this information into the formulation of their bids. 
on energy development in growth areas.”82 Strathcona County was told that it could put forward requests to an appropriate member of the CMRDC. ${ }^{83}$ One wonders, however, how this avenue could possibly address the concerns of the County over oil and gas development with respect to private land, which the CMRDC does not deal with. As well, the effectiveness of this type of input is questionable given that there is no legislative requirement for the municipality's concerns to actually be submitted to, or considered by, the CMDRC, or by Alberta Energy for that matter. Requests made to Alberta Energy by other stakeholders to allow for input into its rights disposition decision-making process have been denied. ${ }^{84}$

\section{SURFACE RIGHTS}

Holders of mineral rights will seek approvals for surface access either from the surface landowner in the case of private land, or from Alberta Sustainable Resource Development (SRD) in the case of public land.$^{85}$ Where such consent is denied, oil and gas rights holders may obtain a right of entry order from the Surface Rights Board (SRB). ${ }^{86}$ In the case of oil and gas facilities, SRB rights of entry must be consistent with the ERCB licence or approval granted for the proposed activity. ${ }^{87}$ Along with setting the level of compensation for surface access, the SRB can attach terms and conditions to right of entry orders as long as they do not make the order inconsistent with the ERCB's licence or approval. ${ }^{88}$

Like the mineral rights disposition stage, there is currently no formal process for public participation at the surface rights disposition stage with respect to Crown lands. Decisions over surface access ultimately add to the determination of the location, pace, and impacts of oil and gas development. Although SRD has issued a statement about public involvement in the use of public lands, it reveals a highly informal and discretionary process. The document grants land managers broad discretion to assess "the need for public involvement" based on a number of factors, including "the degree of change to the use of the land" and "the amount of public interest that is likely to result from the land use decision." 89 Although consultation may or may not include co-operating with municipal governments to "obtain public input on issues of common interest," "90 there is no requirement to consult with affected municipalities.

See Strathcona County, Quarterly Report, supra note 70 at 3.

Ibid.

See e.g. “CBM Drilling in Natural Areas Ignores Public Interests, Conservation Groups Say” Enviroline 17:7-8 (March 2007) 6, which discusses Alberta Energy’s denial of a request by conservation groups to allow for them to provide input into Alberta Energy's rights disposition decisions in regard to a protected natural area of the province.

See the Surface Rights Act, R.S.A. 2000, c. S-24, ss. 1(h), 12, 15(1) [SRA]. Companies wishing to access provincial lands for oil and gas activities must obtain a lease, licence, or other agreement under the Public Lands Act, R.S.A. 2000, c. P-40 [PLA]. They must also consult with, and obtain the consent of, any existing surface rights holders on that land.

SRA, ibid., s. 12. The SRA applies to all public and private lands in Alberta, except land within a Métis settlement (s. 2(1)).

Ibid., s. 15(6).

See e.g. Nigel Bankes, "The relationship between the well licence jurisdiction of the Energy Resources Conservation Board and the jurisdiction of the Surface Rights Board” ABlawg (9 May 2008), online: The University of Calgary Faculty of Law Blog on Developments in Alberta Law <http://ablawg.ca/wpcontent/uploads/2008/05/nb_encana_-v_-campbell_may_6_-2008.pdf>.

Government of Alberta, About Public Lands: Public Involvement in Local Land Use Decision-Making (Edmonton: Alberta Sustainable Resource Development, 1997) at 1, online: Alberta Sustainable Resource Development <http://www.srd.alberta.ca/MapsFormsPublications/Publications/pdf/Public InvolvementLocalLandUseDecisionMaking-Jul-1997.pdf>. Ibid. 
Another SRD document states that because “many activities can affect local land use patterns and municipal services, the government consults with municipalities on most applications before making a decision" in regard to dispositions under the $P L A .{ }^{91}$ Still, there is no information on when or how this consultation occurs. Ultimately, whatever the practice, there is no statutorily-mandated consultation and review process allowing municipalities to be involved in some way in the government's surface access disposition decision-making process.

\section{OIl ANd Gas Project Approvals}

The key regulator of oil and gas projects in Alberta is the ERCB. The Board issues the main licences and approvals for oil and gas wells and facilities by considering whether the proposed project is in the public interest, having regard to the social, economic, and environmental effects of the project. ${ }^{92}$ According to the Board, this requires it to identify the elements of the proposed project that would benefit not only the applicant and those directly connected to the project, but Albertans in general. The Board must then "weigh those benefits against the risk factors that are present, given the nature of the development, the location proposed, and other factors associated with the specific situation." ${ }^{\text {"93 }}$ The Board has emphasized that a finding that a project is in the public interest does not mean that there will be no site-specific impacts. Rather, the Board must ensure "that any site-specific or local impacts are mitigated to an appropriate and acceptable level."94

Terms and conditions may be specified by the ERCB in project approvals in regard to how development will proceed and the way ongoing operations will be conducted. Without specific terms and conditions, generally applicable rules and regulations apply. After project approval, the Board has primary ongoing regulatory authority over oil and gas activities. ${ }^{95}$

\section{STANDING BEFORE THE ERCB}

Proponents applying to the ERCB for oil and gas licences or approvals must follow the requirements set out in its Directive 056. ${ }^{96}$ Unless there is an objection raised or the Board so directs, most applications follow a routine approval procedure, meaning that if the

Government of Alberta, About Public Lands: Co-ordinating Land Use Planning on Public Lands with Municipalities (Edmonton: Alberta Sustainable Resource Development, 1997) at 2, online: Alberta Sustainable Resource Development <http://www.srd.alberta.ca/MapsFormsPublications/Publications/ Documents/CoordinatingLandUsePlanningonPublicLandsWithMunicipalitiesOCT1997.pdf>.

Energy Resources Conservation Act, R.S.A. 2000, c. E-10, s. 3 [ERCA].

Compton: Okotoks, supra note 7 at 12.

Ibid. at 13 .

There are some minor exceptions. For example, Alberta Environment is responsible for issuing the final reclamation certificate for oil and gas sites: see the Environmental Protection and Enhancement Act, R.S.A. 2000, c. E-12, Part 6 [EPEA]. Alberta Environment is also involved prior to approval in some cases. Under Part 2 of the EPEA, for example, Alberta Environment is responsible for conducting environmental impact assessments (EIA) in the case of certain large oil and gas developments. Where an EIA is undertaken, a municipality, as a party "directly affected by the proposed activity" can submit a "statement of concern" to be taken into account in the preparation of the EIA report (s. 44). Alberta Environment then forwards the EIA report to the ERCB for consideration during its regulatory review. The drilling, construction, operation, or reclamation of oil and gas wells are, however, excluded from the EIA process under the EPEA, thereby removing the possibility of municipalities being involved in such a process with respect to the majority of oil and gas installations within their borders. See also the Environmental Assessment (Mandatory and Exempted Activities) Regulation, Alta. Reg. 111/93. Directive 056, supra note 2. 
application complies with all Board requirements, it will be approved. A non-routine application is triggered when a concern or objection raised remains unresolved. ${ }^{97}$

Although the Board requires (or in some cases, expects) companies to consult with various stakeholders, including local governments, prior to submitting their applications, ultimately it is only persons whose rights may be "directly and adversely affect[ed]" by a proposed project that will be granted standing to trigger a public hearing before the Board in regard to the application..$^{98}$ Parties that do not have standing may be allowed (at the Board's discretion) to participate in a hearing if one is held (because it has been triggered by someone with standing), but they normally will not qualify for reimbursement of any costs. They are also granted full participation rights to, for example, make arguments, lead evidence, and cross-examine witnesses only at the Board's discretion and not as a matter of right. If the party that triggered the hearing withdraws and there is no other party with standing, the Board can grant the application and cancel the hearing. ${ }^{99}$

ERCB standing decisions have been the subject of numerous court applications ${ }^{100}$ and scholarly criticism. ${ }^{101}$ The Board considers each request for standing on a case by case basis to determine potential impacts and considers the following: whether the proposed project has the potential to affect the safety, economic, or property rights of the party requesting standing (including, for example, "impacts in relation to contaminants in water, air, or soil or from noise; negative interference with livelihood or commercial activity on the land; damage to property; and concerns for the safety of persons or animals”); whether the party requesting standing is affected "in a different way or to a greater degree than members of the general public"; and whether the party can show "a reasonable and direct connection between the activity complained of and the rights or interests [it believes are] affected."102

Ibid. at para. 3.8.2.

ERCA, supra note 92, s. 26(2). See also ibid. at Appendix 11. Directive 056 sets out minimum requirements and expectations, based on the type of development, for participant involvement prior to the filing of an application. Some parties are entitled to personal consultation, others only to notification of a pending application. For discussion of the ambiguities in Directive 056, see Vlavianos, Oil Sands Development, supra note 73 at 34-44. Although municipalities may have the opportunity to identify potential local impacts and community issues during this pre-application consultation phase, even without consensus, the applicant can proceed with its application to the Board.

99 See Directive 056, ibid. at Appendix 12; ERCB, Directive 029: Energy and Utility Development Applications and the Hearing Process (Calgary: ERCB, 2003) at 8 [Directive 029]; Compton Petroleum Corporation: Applications for Licences to Drill Six Critical Sour Natural Gas Wells, Reduced Emergency Planning Zone, Special Well Spacing, and Production Facilities - Okotoks Field (Southeast Calgary Area), Prehearing Meeting Decision, EUB Decision 2003-088 (18 November 2003), where the Board explains its practice of allowing "those persons who would otherwise not have standing to participate to some extent at a public hearing, provided that they offer relevant information" (at 4). Most recently, see Kelly v. Alberta (Energy Resources Conservation Board), 2009 ABCA 349, 464 A.R. 315; Graff v. Alberta (Energy and Utilities Board), 2008 ABCA 119, [2008] A.J. No. 277 (QL); Sawyer v. Alberta (Energy and Utilities Board), 2007 ABCA 297, 422 A.R. 107. On the utilities side, where the same test for standing is used with respect to the Alberta Utilities Commission, see especially Cheyne v. Alberta (Utilities Commission), 2009 ABCA 94, [2009] A.J. No. 257 (QL).

101 See e.g. Nickie Vlavianos, The Potential Application of Human Rights Law to Oil and Gas Development in Alberta: A Synopsis, Human Rights Paper \#5 (Calgary: Canadian Institute of Resources Law, 2006); Shaun Fluker, "Standing Against Public Participation at the Alberta Energy and Utilities Board" ABlawg (12 December 2007), online: The University of Calgary Faculty of Law Blog on Developments in Alberta Law < http://ablawg.ca/wp-content/uploads/2009/07/blog_sf_sawyer_abca_dec2007.pdf>. 
Given the socio-economic, environmental, and land use impacts of oil and gas development and the municipal jurisdiction over infrastructure, roads, emergency response, and local land use planning as outlined earlier, one would think that municipalities should almost always be able to meet the Board's test for standing. And yet in two recent decisions, discussed below, the Board has denied standing to municipalities. ${ }^{103}$

The first decision came as a result of an application to drill two sour crude oil wells near Rocky Rapids, Alberta. ${ }^{104}$ The responsible municipality, Brazeau County, presented itself as a concerned party and requested intervener status before the ERCB. The County stated that its request for standing was based on its legal obligations under disaster services legislation requiring it to protect the safety of its constituents. In a terse response, the Board concluded that the County was unable to establish a connection between its interests and the proposed activity. The Board concluded as follows:

The Board notes that the County is a local authority that has responsibilities under the Disaster Services Act, as well as under the Municipal Government Act. The applications in question do not affect its authority under these acts. In particular, a local authority must ensure that its emergency response plan (ERP) is coordinated with the site-specific response plan proposed by the applicant. ${ }^{105}$

Although this very requirement of ensuring that its ERP is coordinated with that of the company seems to illustrate the municipality's affected interest, the Board concluded that the County had not shown the "manner in which these applications may directly and adversely affect its rights." ${ }^{106}$ Nonetheless, since a hearing was to be held anyway (because it was triggered by someone with standing), the Board concluded that the County could participate fully since its full participation "by way of submission of evidence, cross-examination, and argument on issues of concern to the County in the hearing would be of significant value and assistance to the Board." 107 If so, one wonders why the Board would not have wanted this information from the County even if there had been no one to trigger a hearing.

The second decision in which the ERCB denied standing to a municipality related to an application for a licence to drill an exploratory sweet gas well within the Eastern Slopes of the province. ${ }^{108}$ The Municipal District (MD) of Pincher Creek, within whose jurisdiction the well was to be drilled, requested standing to trigger a hearing. It argued that, as an elected government, it represented concerns and issues within its jurisdiction. These included concerns about road use and maintenance, surface water and groundwater contamination, weed control, and the loss of fescue grasslands in the area. ${ }^{109}$ The MD wanted the well licence withheld until the company addressed its concerns. In denying the MD standing to trigger a hearing, the Board did not expressly challenge the MD's assertion that it had genuine interests that may be directly and adversely affected by this project. Rather, the

There is a further decision wherein the Board expressed doubt as to whether a municipality had standing, but it was prepared to consider further information on the issue from the municipality: see PetroCanada: Prehearing Meeting, Applications for Wells and Associated Pipeline and Facility Licences Sullivan Field, ERCB Decision 2008-029 (16 April 2008). West Energy 2006-116, supra note 7.

Ibid. at 2. The Disaster Services Act has been replaced by the EMA, supra note 30.

West Energy 2006-116, ibid.

Ibid.

Compton: Eastern Slopes, supra note 7.

Ibid. at 3. 
Board denied standing because "the MD said that it has authority respecting road use and weed control, and therefore the Board believes that the MD can address its concerns respecting those matters through its own authority."110 Moreover, according to the Board, some of the MD's concerns were "general in nature" and not specific to the particular well in question. ${ }^{111}$ Nonetheless, the Board acknowledged that the MD did in fact have legitimate concerns about the company's area development plan and told the company that it expected open and diligent communication with the MD. ${ }^{112}$ Again, however, one wonders why, if these are legitimate concerns, a municipality cannot trigger a hearing before the Board on the basis of these very concerns. Ultimately, if no one else triggers a hearing and a municipality is allowed to participate, it is not at all clear how local impacts and community interests will be represented in the Board's project approval process (and its consideration of the public interest).

There have been calls for greater local government involvement in ERCB decisionmaking. In 2000, after extensive public consultations, the Provincial Advisory Committee on Public Safety and Sour Gas recommended that the Board develop a system to involve municipalities "in relevant [Board] policy making and, where applicable, for their early, efficient, and effective involvement in the review of applications dealing with sour gas and public health and safety."113 In 2004 the Board responded with a draft protocol that envisioned it seeking input from municipal associations and the Ministry responsible for municipal affairs in the development of Board policy and "requirements on matters related to oil and gas development, such as setback requirements for wells, facilities and pipelines, emergency response plans and calculation of emergency response zones."114 The protocol also expressed a commitment to ensure that the Board's application process is effective in addressing municipal needs and interests, as well as to establish a process to facilitate local/regional dialogue with municipal authorities on matters relating to oil and gas operations in their respective areas. ${ }^{115}$ The protocol was to be in place for a two-year trial period that would have ended in 2007 at the latest.

Although there is no publicly available information about the protocol's implementation, Board comments in a recent decision suggest that it is still ongoing in some way. In Highpine Energy, in response to concerns raised by Parkland County about its ability to fund adequate emergency response and other services associated with the drilling of six sour gas wells, the Board stated as follows:

Ibid. at 8 .

Ibid. Similarly, in Petro-Canada, supra note 7 at 8, the Board stated that the MD of Ranchland had failed to "identify specific legal rights or interests to lands within the project area or advance any other potential direct and adverse impacts associated with the project" [emphasis added]. Clearly, the Board is focused on site-specific impacts only rather than cumulative effects. Compton: Eastern Slopes, ibid.

Provincial Advisory Committee on Public Safety and Sour Gas, supra note 79 at 26.

Government of Alberta, Protocol for Coordination Between the Alberta Energy and Utilities Board (EUB), Alberta Association of Municipal Districts and Counties (AAMDC), Alberta Urban Municipalities Association (AUMA), and Alberta Municipal Affairs (MA) (Calgary: ERCB, 2004) at 1-2, online: ERCB <http://www.ercb.ca/docs/public/sourgas/PSSG_Rec34_LocalAuthoritiesProtocol.pdf> [Protocol for Coordination]. See also "EUB Reaches out to Municipalities and Health Authorities" across the board (May 2005) 3; Alberta Energy and Utilities Board, Public Safety and Sour Gas: Final Report (Calgary: Alberta Energy and Utilities Board, 2007) at 22.

Protocol for Coordination, ibid. at 1. 
The Board welcomes the feedback from the county and acknowledges the need for close and mutually supportive efforts to achieve a common need to ensure public safety, as well as achieve a balance on energy development and public and environmental issues. The ERCB works closely with Alberta Association of Municipal Districts and Counties and the Alberta Urban Municipal Association under a memorandum of understanding developed as part of the public safety and sour gas initiative and has frequent contacts with counties across this province. ${ }^{116}$

This memorandum of understanding must refer to the 2004 protocol noted above. There is, however, no easily accessible publicly available information about how this memorandum of understanding works in practice, or its effectiveness to date.

\section{INTERVENER COSTS}

Along with difficulties in obtaining standing, municipalities face another hurdle to effective participation in the ERCB project approval process. Outside of the unique situation of a municipality having standing because it owns an interest in land affected by a proposed project, a municipality will not normally be entitled to costs for participating in any hearing. Given the limited resources of many Alberta municipalities, this is a significant barrier for municipalities.

The provision allowing the ERCB to make an award of costs is narrower than that entitling a party to standing or full participation at a hearing. Section 28(1) of the ERCA authorizes the Board to award costs for persons, groups, or associations who, in its opinion, have an interest in, are in actual occupation of, or are legally entitled "to occupy land that is or may be directly and adversely affected” by a Board decision. ${ }^{117}$

Where a municipality participates in a hearing but cannot meet this test, it will not be entitled to costs. In three oil sands mining applications, although allowed to participate fully in the hearings, the RMWB was denied costs. The Board held that s. 28(1) was intended to benefit persons with legally recognized interests in specific lands who chose to participate in a Board proceeding "in order to safeguard the benefits they are entitled to enjoy by virtue of their ownership of those interests." 118 According to the Board, the RMWB's intervention was undertaken pursuant to legislative mandates to defend and advance the collective interests of the residents in the area. This was not the type of intervention contemplated by s. 28(1). Although the Board found the municipality's participation valuable in regards to the regional socio-economic issues raised at the hearing, it noted that the RMWB focused on regional socio-economic issues arising from the pace and scale of development in the area generally, as opposed to more site-specific issues arising directly from the applications. This was not, in the Board's opinion, the type of intervention entitled to costs under s. 28(1). ${ }^{119}$

$116 \quad$ Supra note 7 at 33.

117 Supra note 92.

118 Albian Sands Energy Inc.: Application to Expand the Oil Sands Mining and Processing Plant Facilities at the Muskeg River Mine, EUB Energy Cost Order 2007-003 (14 March 2007) at 7.

119 Ibid. The Board reached the same conclusion in Suncor Energy Inc.: Application for Expansion of an Oil Sands Mine (North Steepbank Mine Extension) and a Bitumen Upgrading Facility (Voyageur Upgrader) in the Fort McMurray Area, EUB Energy Cost Order 2007-001 (21 February 2007). Leave to appeal both cost orders was denied by the Alberta Court of Appeal in Wood Buffalo (Regional Municipality of) v. Alberta (Energy and Utilities Board), 2007 ABCA 192, 417 A.R. 222. 
Without the availability to recoup at least some of their costs, one wonders how likely it will be that Alberta municipalities will participate as fully in future applications.

\section{INTERVENER STATUS}

Even if a municipality intervenes in a hearing and makes its concerns about proposed development known, there is no requirement for the ERCB to address them in its decision. Ultimately, the Board has the final word as to whether and how a project will proceed. ${ }^{120}$ Thus, although they are local governments with legislated mandates and responsibilities, municipalities have the same status as any other intervener when it comes to Board decisionmaking. Their views are heard, but there is no guarantee that they will be acted upon or responded to. Perhaps the clearest example of this comes from the three oil sands mining applications wherein the RMWB asked for a delay of further approvals until it was given an opportunity to ensure that it had put in place the social services and infrastructure required to deal with impacts that would result from further development in the region. In each case, although it acknowledged the difficult situation facing the municipality, the Board approved the applications. ${ }^{121}$

Any argument that the views of municipalities must be accorded greater weight than other interveners will likely be unsuccessful. In 1999, the Calgary Regional Health Authority (CRHA) argued before a judge of the Court of Appeal that its views on the health and safety risks posed by the drilling of a sour gas well within city limits should have been considered more seriously by the ERCB. The CRHA said that, because it is legislatively mandated to promote and protect the health of the population in its region, its concerns about public health and safety should not have been "lumped together with [the concerns] of other non-mandated intervenors.” ${ }^{\prime 22}$ In denying the CRHA's request for leave to appeal the ERCB's approval, Hunt J.A. held that, despite its statutory mandate, a regional health authority holds the same status as any other intervener before the Board. Although statutory responsibilities of other entities may overlap with those of the Board, the ERCB would not be able to fulfill its obligation to determine whether a project is in the public interest if it had to pay special attention to the arguments of other entities having their own statutory mandates. According to Hunt J.A., there is nothing in the Board's legislation "to suggest that such a category of 'super-intervener' was ever contemplated by the Legislature." ${ }^{23}$ Although not a panel decision, there is little reason to think that a similar conclusion would not be reached in the case of municipalities.

\section{SOUR OIL AND GAS AND EMERGENCY RESPONSE PlanNing}

There is a wild card available in some instances to municipalities at the oil and gas project approval stage. Ironically, although they have no final say on whether and what projects get approved, municipalities are, as noted earlier, responsible for responding to all emergencies resulting from oil and gas development. Where applications to the ERCB involve certain sour

ERCA, supra note 92, s. 3.

See supra note 8 and accompanying text.

Calgary North $\mathrm{H}_{2}$ S Action Committee v. Alberta (Energy and Utilities Board), 1999 ABCA 323, [1999]

A.J. No. 1284 at para. 14 (QL).

Ibid. at paras. 17-18. 
oil or gas wells and facilities, current requirements offer municipalities the ability to at least ensure that their concerns with respect to public safety and emergency response are adequately addressed. Recent experience has shown that failure to reach agreement with the affected municipality on emergency response planning can undermine an application.

The ERCB requires companies to submit site-specific emergency response plans (ERPs) for riskier sour oil and gas wells and facilities. ${ }^{124}$ An ERP contains information necessary to respond effectively to an emergency. The type of information varies depending on the potential hazards identified. ${ }^{125}$ Information regarding all resources that could be called upon in an emergency must be included in an ERP, and the ERP must set out the roles and responsibilities of all emergency responders (for example, local authorities, health authorities, and other agencies who have a role in providing effective response). ${ }^{126}$

To develop their ERPs, companies must consult with municipalities to "confirm and coordinate each party’s roles and responsibilities." 127 According to Directive 071, “[u]nder Section 11 of the Emergency Management Act, the local authority of each municipality is responsible for the direction and control of the local authority's emergency response.”128 Thus, in order to ensure that there is no confusion or misunderstanding as to the roles and responsibilities in the event of an emergency, the ERCB requires operators to "attempt to reach a mutual understanding with local authorities on the specific needs and roles and responsibilities of each party during an emergency and include a summary of the roles and responsibilities in its ERP reflecting the mutual understandings.”129

The co-operation of municipalities is thus critical for emergency response planning. In a recent application, the company suggested that the ERP could be implemented on its own without the assistance of the county. The Board responded as follows:

\footnotetext{
The Board is of the view that responsibilities of all agencies potentially involved in emergency response should be included in an ERP. The Board agrees that Highpine's approach was correct in outlining areas where Brazeau County may be able to provide assistance in the case of an emergency. The Board is of the view that this approach will ensure that roles and responsibilities are clearly outlined to ensure that an effective response would take place. ${ }^{130}$
}

The potential for municipalities to affect the course of oil and gas development through the ERP process was highlighted in 2006 when the ERCB closed Compton Petroleum Corporation's (Compton) controversial application to drill six sour gas wells southeast of Calgary. ${ }^{131}$ The Board had earlier approved the drilling of four wells on a number of

Directive 071, supra note 2. Sour oil and gas refers to oil or gas containing hydrogen sulphide or $\mathrm{H}_{2} \mathrm{~S}$ : see EnerFAQs, supra note 42 at 2.

Directive 071, ibid. at 6.

Ibid. at 7.

Ibid. at 15-16.

Ibid. at 16.

Ibid.

Highpine Oil \& Gas Ltd.: Applications for Well Licences — Pembina Field, EUB Decision 2008-018 (6 March 2008) at 19.

131 Alberta, Energy and Utilities Board, News Release, NR 2006-01, “EUB Closes Compton Critical Sour Gas Well Applications” (4 January 2006). 
conditions, including the filing of an ERP by a specified deadline. ${ }^{132}$ To meet this deadline, Compton was required to work with the City of Calgary (and the CRHA) to develop an acceptable and workable ERP. Compton said that it was the failure by the City and the CRHA to co-operate adequately in these negotiations that prevented it from filing the ERP as required. ${ }^{133}$ The municipality thus directly affected Compton's ability to proceed with this project.

Ultimately, failure to reach agreement on emergency roles and responsibilities can impact the outcome of a particular project. Although this gives municipalities at least one window of opportunity to have their concerns addressed, it is only available with respect to those projects that require the development of an ERP. ${ }^{134}$

\section{The Regulation OF OIL AND GAS DEVELOPMENT By MuniCiPAlities}

As noted, municipalities are not, despite their status as elected governments and their statutory mandates and responsibilities, consulted in any direct way when the provincial government sets its energy policy, establishes land use plans for the province, disposes of rights to develop Crown-owned oil and gas resources, or grants access to the surface of public lands. At the project approval stage, municipalities may be able to have their concerns addressed by working directly with the company involved; an advisable route wherever possible. Where agreement is not possible, however, municipalities face significant hurdles to having their concerns address by the ERCB. First, they may not be granted standing to trigger or participate fully in a hearing. Second, in most cases they will not be entitled to costs for participating in a hearing, thereby reducing the chance that they will participate as fully or as effectively as may otherwise have been the case. Third, even if they do participate, there is no requirement for the Board to specifically address their views and concerns in its approval. The final approval decision, along with its terms and conditions, rests with the Board alone.

This state of affairs leads one to ask whether municipalities have any ability to regulate oil and gas development in some way through their own statutory powers. Although the ultimate project approval decision rests with the ERCB, are municipalities empowered to impose any of their own terms and conditions on oil and gas development? Could they, in the face of rules and regulations established by the Board and other provincial agencies ${ }^{135}$ establish their own rules around, for example, flaring, noise, and setbacks? These questions are addressed below.

Compton: Okotoks, supra note 7.

See Renata D’Aliesio, “The Compton factor” Calgary Herald (8 January 2006) B1; Renata D’Aliesio, "Regulator refuses Compton delay" Calgary Herald (22 December 2005) B1. See also Nickie Vlavianos, "The Role of Municipalities and Regional Health Authorities in Oil and Gas Development in Alberta" Resources 94 (Spring 2006) 1, online: Canadian Institute of Resources Law < http://dspace.ucalgary.ca/ bitstream/1880/47046/1/Resources94.pdf> [Vlavianos, "The Role of Muncipalities"].

Another wild card municipalities hold in terms of their bargaining position with industry post-approval is their authority over roads. In practice, the process of obtaining road use permits (and the possible imposition of road bans) can have important effects on the timing of drilling and construction for oil and gas operators.

For example, Alberta Environment, who sets guidelines and standards for air and water quality and reclamation. 
Two sources of municipal powers are particularly relevant. They are the jurisdiction granted to municipalities over local land use planning and development in Part 17 of the $M G A$, and the general bylaw-making powers granted in Part 2 of the Act.

\section{A. Part 17 of the Municipal Government ACt - Planning and DeVelopment}

As noted above, a key power granted to Alberta municipalities is their power to control and regulate land use and development within their boundaries through the adoption of various statutory planning tools, including a land use bylaw that sets the course for subdivision and development decision-making in the municipality. Generally, Part 17 of the MGA requires an application to the municipality for a development permit or subdivision approval before land can be developed or subdivided. Can municipalities use these powers to determine the course of oil and gas development within their borders?

\section{SECTION 618 OF THE MGA}

With respect to oil and gas wells, batteries, and pipelines, the answer is an unequivocal "no." Pursuant to s. 618 of the MGA, where a development or subdivision is effected only for the purpose of an oil and gas well, battery, or pipeline (or an installation or structure incidental to the operation of a pipeline), Part 17 and the regulations and bylaws made under it do not apply. ${ }^{136}$ Thus, companies proposing to drill a well or install a battery or pipeline are not required to apply to the relevant municipality for a development permit or subdivision approval; nor do a municipality's statutory plans and land use bylaws apply to that development. Consequently, the vast majority of oil and gas operations in Alberta are specifically exempted from municipal land use planning and regulation. It has been said that the Alberta legislature's enactment of s. 618 reflects the fact that such operations undergo an approval process through the ERCB and recognizes that, as the lifeblood of Alberta's economy, oil and gas operations should "not be subjected to local control that might vary from place to place.”137

Still, where a public hearing in regard to a proposed well or pipeline has been held, the ERCB has considered land use impacts and municipal plans in its consideration of whether a particular project is in the public interest. In a 1999 application, for example, the Board looked at land use impacts when reviewing Canadian 88 Energy Corporation's application to drill a sour gas well 11 kilometres northwest of the City of Calgary. ${ }^{138}$ Despite the fact that the company was not required to obtain municipal development approvals, the Board considered the MD of Rockyview's area structure plan for lands near the proposed well site. The plan outlined continued subdivision and residential growth, as well as the current zoning for the area around the proposed site, which was primarily agricultural. The Board concluded that the proposed well was consistent with current land use zoning, but it noted that if the

Because the reference in the MGA, supra note 13, s. 618, is to wells "within the meaning of the Oil and Gas Conservation Act," this includes a broad range of oil and gas wells, including wells associated with in situ oil sands operations. where they occur and developments to extract the resource cannot be easily moved based on changes in local planning bylaws or goals": Understanding Land Use, supra note 21 at 24. 
well were found to be commercial, it expected "future developments to take into account the conflicting priority of resource recovery and residential growth.”139

Similarly, in a 2005 application for a licence to drill a sour gas well and install an associated battery and pipeline, the Board acknowledged the importance of municipal land use planning when considering the impacts of wells, batteries, and pipelines, notwithstanding s. 618 of the MGA. The Board noted that its Directive 056 public consultation expectations include the project proponent demonstrating "clear evidence that it has ... met the special needs of local authorities." ${ }^{140}$ In this case, the County of Wetaskiwin led evidence that a longstanding priority reflected in its planning documents and bylaws was the protection of the Battle Lake Watershed. Concerns were raised about whether the applicant's proposed operations would contribute to the proliferation of oil and gas development in the area, thereby thwarting this goal of watershed protection. The Board concluded that applicants should be aware of municipal planning processes and bylaws and "should incorporate them into development planning to the greatest extent possible, especially where special circumstances exist, such as the establishment of the watershed protection district." ${ }^{141}$

Thus, despite s. 618 of the MGA, it is clear that municipalities should still address oil and gas development and its impacts in their policies, statutory plans, and land use bylaws. Such documents can be used in negotiations with the company prior to submission of its application. As well, they may be taken into account by the ERCB, at least where a public hearing is held. As noted earlier, Strathcona County has developed a protocol that outlines its views on various oil and gas issues, including flaring and reclamation. It asks oil and gas operators to adhere to this protocol as much as possible; it also works with the ERCB to ensure compliance with the protocol. ${ }^{142}$

It is also clear that municipalities must, as much as possible, take an active role in raising any concerns about potential impacts of proposed oil and gas development with the ERCB. The Board has said that it "believes that counties and municipalities also share a responsibility to assess any potential impacts of a proposed energy development on their community and to engage the [Board] processes as appropriate to present their assessment to the Board." ${ }^{143}$ Without such active involvement it is unclear to what degree, if any, the Board will consider municipal plans and concerns in its decisions. As noted, unless objections are raised, most applications proceed as routine. That said, if the Board continues to take a restrictive approach to granting municipalities standing, it is not at all clear how their land use concerns could be heard by the Board in cases where a hearing has not been triggered.

Ibid. at 11.

Ketch Resources Ltd.: Review of Well Licence No. 0313083 and Application for Associated Battery and Pipeline - Pembina Field, EUB Decision 2005-129 (1 December 2005) at 8 [Ketch Resources]. Ibid. at 9.

Strathcona County has also established an Energy Exploration Liaison officer to work with industry and the Board to meet the County's expectations and concerns: see online: Strathcona County <http://www. strathcona.ca/Strathcona/Departments/Engineering_and_Environmental_Planning/oil-and-gas-instrathcona-county.aspx>.

Ketch Resources, supra note 140 at 8. 


\section{SECTION 619 OF THE MGA}

As noted, s. 618 of the MGA deals only with oil and gas wells, batteries, and pipelines. What about other oil and gas operations, such as processing plants, upgraders, oilfield waste facilities, refineries, and oil sands mines? For these, Part 17 of the MGA applies, and so municipal planning approvals are required, but s. 619 of the Act again significantly curtails the ability of municipalities to regulate independently of the Board. Section 619 states as follows:

(1) A licence, permit, approval or other authorization granted by the NRCB, ERCB, AEUB or AUC prevails, in accordance with this section, over any statutory plan, land use bylaw, subdivision decision or development decision by a subdivision authority, development authority, subdivision and development appeal board, or the Municipal Government Board or any other authorization under this Part.

(2) When an application is received by a municipality for a statutory plan amendment, land use bylaw amendment, subdivision approval, development permit or other authorization under this Part and the application is consistent with a licence, permit, approval or other authorization granted by the NRCB, ERCB, AEUB or AUC, the municipality must approve the application to the extent that it complies with the licence, permit, approval or other authorization granted under subsection (1). ${ }^{144}$

Section 619(4) specifies that a hearing held by a municipality under s. 619(2) "may not address matters already decided by" the ERCB “except as necessary to determine whether an amendment to a statutory plan or land use bylaw is required.” Pursuant to s. 619(5), if a municipality does not approve an application under s. 619(2) to amend a statutory plan or land use bylaw, the applicant may appeal to the Municipal Government Board (MGB), which may either dismiss the appeal or order the municipality to amend the plan or land use bylaw so as to comply with the Board's licence, permit, or other authorization. ${ }^{145}$ Notably, s. 619 does not say, however, that municipalities cannot address oil and gas development in their land use plans and bylaws. ${ }^{146}$

The ERCB has considered the effect of s. 619 in several decisions. In July 2000, Shell Canada Ltd. (Shell) applied to construct a natural gas-fired cogeneration plant in Strathcona County. ${ }^{147}$ An issue arose as to whether the County's current planning documents supported this heavy industrial use. Shell argued that, because of s. 619 of the MGA, the municipality's particular land use designation was irrelevant to the Board's consideration of the project. It

Supra note 13.

Ibid., s. 619(8). For more discussion on s. 619, see Laux, supra note 26; P.S. Elder, “Alberta's 1995 Planning Legislation” (1996) 6 J. Envtl. L. \& Prac. 23; Vlavianos, “The Role of Municipalities,” supra note 133; Nickie Vlavianos, "Municipal Regulation of Oil and Gas Development” LawNow 30:1 (August/September 2005) 17 [Vlavianos, "Municipal Regulation”]; Constance D. Hunt, Alastair R. Lucas \& Jenette Yearsley, eds., Canada Energy Law Service: Alberta, looseleaf (Toronto: Carswell, 2007) at $\S \S 76-78$.

Assuming the difference in language between ss. 618-19 of the MGA, ibid., is not simply the result of patchwork legislating, one can speculate that it likely relates to the perceived difference in size and impact of wells, batteries, and pipelines (s. 618) and processing plants, refineries, etc. (s. 619). The logic must be that there are more details associated with larger projects that municipalities should be involved with. Given the pace and intensity of well and pipeline development in recent years, however, one wonders if this rationale still holds.

Shell Canada Ltd.: Cogeneration Plant and Hydrogen Pipeline - Fort Saskatchewan Area, EUB Addendum to Decision 2000-30 (25 July 2000). 
said that the Board must decide whether the project is in the public interest, and not whether it is compatible with existing municipal land use designations. ${ }^{148}$ For its part, the County argued that, because s. 619 effectively makes the Board the final arbiter of land use issues where oil and gas projects are concerned, the Board must take municipalities' land use planning laws into account. If the Board declined to do so, Albertans and municipalities would be deprived of an effective forum for dealing with land use matters arising from oil and gas activities. ${ }^{149}$

The Board concluded that s. 619 of the MGA gives Board "licences and approvals precedence over land-use bylaws or other planning instruments enacted by municipalities, as well as over decisions of local development appeal boards or other planning agencies."150 Nonetheless, the provision does not allow the Board to assume municipal authority for land use planning pursuant to the MGA. Land use planning remains the domain of municipal governments. That said, in determining the public interest, the Board held that it may be required to consider land use issues. ${ }^{151}$ For example, the land use impacts on neighbouring lands from Shell's proposed project was a matter requiring Board consideration.

Again in 2000, the Board heard argument on its role vis-à-vis municipal land use planning. ${ }^{152}$ EPCOR Generation Inc. (EPCOR) had requested approval to construct and operate an additional natural gas-fired turbine at its Rossdale power plant in Edmonton. At the prehearing meeting, a question arose about whether the Board should consider land use planning issues or defer its consideration of the application until municipal development permits were applied for. The Board concluded that it did not have to delay its approval until municipal approvals were obtained. In its view, although there may be some overlap in the issues the Board and municipalities look at, the Board's mandate does not require it to consider land use planning issues generally. It stated as follows:

[T] ]e Board is of the view that Section 619 of the MGA neither requires the Board to consider land-use planning issues properly within the jurisdiction of the City nor to defer its consideration of EPCOR's application pending the outcome of the municipal development permit process. The Board believes that Section 619 contemplates that the Board's process will be carried through to completion prior to the City considering subdivision or development permit applications. The Board does not believe that Section 619 transfers to the Board or otherwise usurps jurisdiction over land-use planning matters otherwise within municipal jurisdiction. Section 619 recognizes that there may be some overlap in the Board's consideration of an application and that of a municipality. It does not require the Board to carry out the municipality's responsibilities under its own legislation. The Board has on a number of occasions stated that land-use planning issues are within municipal jurisdiction. ${ }^{153}$

Nonetheless, the Board again agreed that the impacts of the proposed project on adjacent lands was a land use issue properly within its mandate. Consequently, it allowed evidence to be led relating to the present and historic nature of land use planning policies, plans, and

\footnotetext{
$148 \quad$ Ibid. at 8-9.

$149 \quad$ Ibid. at 9.

$150 \quad$ Ibid. at 11.

151 Ibid.

152 Prehearing Meeting: EPCOR Power Development Corporation and EPCOR Generation Inc., ATCO Pipelines, EUB Memorandum of Decision (30 May 2000). 
instruments of the river valley along which the plant operated. In its view, this evidence would allow the Board to appreciate better the effects of the Rossdale power plant on the usage of the river valley. ${ }^{154}$

Elsewhere, the Board has stated that land use planning regimes are relevant for determining the impacts on the use of land both at the proposed site as well as with respect to adjacent lands. In its view

[1]and use planning regimes are ... relevant to the Board's consideration because they indicate from the municipality's perspective, the nature of the past, present, and future uses of a proposed site or lands in close proximity to a site. The Board is thus better able to determine whether the relative impacts created by energy facilities on the use of land are acceptable. ${ }^{155}$

Despite their relevance, however, the Board has clearly stated that it does not consider itself bound or constrained by any planning tools of a municipality in making its decision. ${ }^{156}$ In the case of the Rossdale power plant, the Board concluded that it

is not bound ... to give expression to the City's land-use policies, plans, and instruments in determining the applications before it. Approval or rejection of the application is based on the public interest criteria contained in the Board's enabling legislation. ${ }^{157}$

In sum, the Board takes the view that it may, but not that it must, consider evidence of current and past municipal land use and development plans, bylaws, and policies. It will do so if it considers this evidence to be relevant to its determination of whether a proposed project is in the public interest. Whether it does so or not, however, the Board has clearly stated that, because of s. 619 of the MGA, it is not bound by any of these plans or bylaws in reaching its decision. As noted, this view has been upheld by one member of Alberta's Court of Appeal and there is no reason to believe that it would not be echoed by a panel of the Court.

\section{a. Some Room for Municipal Control}

On several occasions the ERCB has emphasized the specific language of s. 619 of the MGA. Section 619 gives precedence to Board approvals, but only to the extent that the Board's decision actually deals with land use matters. The Board has stated as follows:

EUB approvals of energy facilities will take precedence over land-use planning instruments enacted by municipalities to the extent that the Board has addressed land-use issues in its decision. The following

Ibid. at 7.

AES Calgary ULC: 525-MW Natural Gas-Fired Power Plant - Application No. 2001113, EUB Decision 2001-101 (11 December 2001) at 4.

Ibid. at 41.

EPCOR Power Development Corporation and EPCOR Generation Inc.: Rossdale Power Plant Unit 11 (RD 11) - Application No. 990289, EUB Decision 2001-33 (8 May 2001) at 11 [EPCOR]. On a leave to appeal application, Berger J.A. held that the Board had properly drawn "a distinction between land use effects which it said were relevant, and land use plans and policies which the Board referenced but ... held [were] properly within the jurisdiction of municipalities": ConCerv v. Alberta (Energy and Utilities Board), 2001 ABCA 217, [2001] A.J. No. 1128 at para. 27(QL). 
passage from Professor F.A. Laux's Planning Law and Practice in Alberta (2d ed.) on page 3-17 is instructive:

\begin{abstract}
Where the NRCB or the AEUB has sanctioned a project that also requires planning approval, the project may not be vetoed or altered in any way by the planning body in respect of considerations and issues that have been addressed by the provincial body. On the other hand, the planning agency's powers remain unfettered in respect of planning considerations and issues that have not been addressed by the provincial body. ${ }^{158}$
\end{abstract}

Thus, in an appeal under s. 619(5) of the MGA concerning an application by AES Calgary Ltd. (AES) to construct a power plant east of Calgary, the MGB emphasized that, although the Board is not constrained by land use planning documents, it had acknowledged that the details of land use planning for the site was to be left to the municipality. AES had obtained Board approval to construct the plant, but when it applied for redesignation of the site to allow for the project, the MD of Rockyview refused to pass the bylaw amendment it had drafted with AES. The MGB concluded that although s. 619 required the MD to pass the bylaw, this did not mean that the municipality was left without any control over planning and development. According to the MGB

[s]ection 619 was written to allow a municipality some control over how a mega-project is developed. There are many planning considerations despite the overall approval issued by a body that is not the municipal council. The MD [of Rockyview] and AES identified those considerations and prepared a comprehensive bylaw amendment which is intended to provide municipal control over the issuing of development and building permits. $^{159}$

The MGB concluded that the effect of s. 619 does not mean that the municipality is without authority or involvement in the implementation of the EUB approval. On the contrary, the municipality retains "substantial control over the issuance of development permits and the rules under which the power plant must be constructed."160 Here, because the Board had not addressed numerous land use matters in its decision, the MGB found that all of the following were local concerns that could properly be addressed by the municipality in a land use bylaw amendment: traffic impacts; access and construction of access roads; construction management; dust and noise control; chemical storage and waste disposal; landscaping; storm and water management; and reclamation. The MGB also held that the municipality could set minimum setback requirements for transmission and cooling towers from any roads; the maximum facility capacity limits and restrictions on the height of buildings and structures; as well as place conditions on the issuance of a development permit, such as requiring the preparation of a satisfactory construction management plan and traffic impact analysis. ${ }^{161}$ All such conditions imposed by the municipality would be consistent with the Board approval pursuant to s. 619 either because they were identical to those given by the Board, or because the Board had not specifically set out the details on these matters in its decision. $<$ http://www.municipalaffairs.alberta.ca/cfml/boardorders/pdf/M091-02.pdf>. Ibid. Ibid. at 32-33, 42-44. 
Thus, there is room for Alberta municipalities to impose some conditions on the way oil and gas development proceeds even though they may not be able to control the overall approval of a project. ${ }^{162}$ Moreover, as in applications for wells, batteries, and pipelines, it is clear that the ERCB will consider relevant municipal planning documents if they are argued before it. ${ }^{163}$ Consequently, it can only benefit municipalities to have such plans and bylaws in place, and the sooner, the better it seems. In Ketch Resources, the Board was especially influenced by the long-standing nature (about 30 years) of the municipality's efforts at protecting the Battle Lake Watershed. ${ }^{164}$

\section{B. PART 2 OF THE MUNicipal Government ACt - General Bylaw-MaKing PoWers}

Given the restrictions on the ability of municipalities to regulate oil and gas development through their planning and development powers, the next question is whether municipalities could use their general bylaw-making powers set out in Part 2 of the MGA to regulate in this context. Oil and gas wells and pipelines are not exempted from the application of Part 2 of the Act, nor are there any provisions giving precedence to ERCB licences or approvals in this part.

Two general bylaw-making powers are particularly relevant. Sections 7(a) and (c) of the $M G A$ empower municipalities to pass bylaws for municipal purposes respecting the "safety, health and welfare of people and the protection of people and property" and respecting "nuisances, including unsightly property." 165 Contrary to the strict approach of the past, Canadian courts have increasingly adopted a broad and purposive approach to the interpretation of such statutory provisions. ${ }^{166}$ This means that in deciding whether a municipality is authorized to exercise a certain power, the specific words in the Act must be "read in their entire context and in their grammatical and ordinary sense harmoniously with the scheme of the Act, the object of the Act, and the intention of Parliament."167 Courts have said that such an approach is consistent with general statutory interpretation and with the modern approach to drafting municipal legislation broadly so as to grant municipalities greater flexibility in fulfilling their statutory purposes. The approach also recognizes the need to respect the decisions of an elected level of government that is closest to the citizens

That said, it has been noted that applicants may be able to shut out municipal planning authority altogether by submitting very detailed proposals to the ERCB, including specifics such as design guidelines and architectural controls, and asking the Board to attach its own rules with respect to setbacks, noise restrictions, flaring, etc. If the Board approves such highly specific applications, such an approval would effectively remove a municipality's ability to regulate over matters not addressed by the Board: see Elder, supra note 145 at 37. Again assuming, of course, that a municipality is granted standing to do so.

Supra note 140 . Supra note 13.

See e.g. Nanaimo (City of) v. Rascal Trucking Ltd., 2000 SCC 13, [2000] 1 S.C.R. 342 [Rascal Trucking]; Spraytech, supra note 5; United Taxi Drivers' Fellowship of Southern Alberta v. Calgary (City of), 2004 SCC 19, [2004] 1 S.C.R. 485 [United Taxi]; Croplife, supra note 25. For discussion of the evolution of judicial approaches to interpreting municipal powers, see Stanley M. Makuch, Neil Craik \& Signe B. Leisk, Canadian Municipal and Planning Law, 2d ed. (Toronto: Thomson Carswell, 2004); Rogers, supra note 16; Marcia Valiante, "Turf War: Municipal Powers, the Regulation of Pesticides and the Hudson Decision” (2001) 11 J. Envtl. L. \& Prac. 327.

Elmer A. Dreidger, Construction of Statutes, 2d ed. (Toronto: Butterworths, 1983) at 87, cited in United Taxi, ibid. at para. 8. 
affected and most responsive to their needs. Without a clear demonstration that a municipality far exceeded its powers, courts should not so hold. ${ }^{168}$

Approaching "health and welfare" provisions such as s. 7(a) of the MGA in this broad and purposive manner has led courts to uphold various municipal bylaws aimed at protecting the health of citizens from environmental impacts. Such bylaws have, for example, been used to control smog, smoking, the aesthetic use of pesticides, and manure management within municipalities. ${ }^{169}$ After Spraytech, commentators concluded that the door was wide open for municipalities to enact a broad range of bylaws to regulate many health, welfare, and safety concerns in the environmental context as long as such bylaws fit with the legislative purposes of municipalities. ${ }^{170}$ According to James Mallet, such bylaws could "address emerging air and water quality concerns, the long-term effects of potentially toxic substances, and other pressing environmental issues."

Spraytech clarified that even if provincial or federal legislation covers the same subject matter, as long as the relevant municipal bylaw is not inconsistent with that legislation, it can stand. To determine inconsistency, the Supreme Court adopted the impossibility of dual compliance test. ${ }^{172}$ Where two levels of legislation exist on the same topic, if it is possible to follow both laws there is no conflict or inconsistency requiring one of the laws to be struck down. Rather, a conflict only arises where following one law requires non-compliance with another. Similarly, s. 13 of the MGA states that "[i]f there is an inconsistency between a bylaw and this or another enactment, the bylaw is of no effect to the extent of the inconsistency." 173

Based on this case law it is arguable, at least as a starting point, that municipalities have the power to regulate for genuine health and safety purposes in the context of oil and gas development. Such a bylaw must not, however, be inconsistent (in the sense of impossibility of dual compliance) with a provincial law or regulation that deals with the same subject matter. ${ }^{174}$

See Shell Canada Products Ltd. v. Vancouver (City of), [1994] 1 S.C.R. 231; Spraytech, supra note 5; Rascal Trucking, supra note 166.

See e.g. Spraytech, ibid.; Croplife, supra note 25; Entreprises Sibeca Inc. v. Frelighsburg (Municipality of), 2004 SCC 61, [2004] 3 S.C.R. 304; Ben Gardiner Farms Inc. v. West Perth (Township of) (2001), 152 O.A.C. 47 (Sup. Ct. J.).

See e.g. Arlene Kwasniak \& Alison Peel, “Municipal Regulation of Pesticide Use” News Brief 16:3 (2001) 7, online: Environmental Law Centre <http://www.elc.ab.ca/Content_Files/Files/NewsBriefs/ MunicipalRegulation-v16-3.pdf>; Michael Bowman \& Michael Millar, "Municipal role in regulating the environment likely to increase" The Lawyers Weekly 22:17 (6 September 2002) 16; Karen E. Jacques, "Municipal Protection of Public Health Through Environmental Regulation" (2007) 36 M.P.L.R. (4th) 37. For negative reaction to Spraytech, see Mary Adkins, Len Griffiths \& Shawna Parr, “The Hudson Decision: An ‘Over-Precautionary’ Approach?” (2002) 51 U.N.B.L.J. 231, where the authors conclude that municipalities lack the necessary experience and resources to deal effectively with environmental matters.

James S. Mallett, Municipal Powers, Land Use Planning, and the Environment: Understanding the Public's Role (Edmonton: Environmental Law Centre, 2005) at 6.

172 In doing so the Court rejected the earlier approach of asking whether one legislative scheme entirely occupied the field to the exclusion of another: Spraytech, supra note 5 at paras. 37-38, citing British Columbia Lottery Corp. v. Vancouver (City of (1999), 169 D.L.R. (4th) 141 at 147-48 (B.C.C.A.). Supra note 13. Because the MGA does not define "inconsistency" for the purposes of s. 13, it is likely that the Supreme Court of Canada's definition from Spraytech would apply.

174 For earlier statements of this argument, see Vlavianos, "The Role of Municipalities," supra note 133 at 4-5; Vlavianos, “Municipal Regulation,” supra note 145. 
Similarly, the power in relation to nuisances granted in s. 7(c) arguably grants municipalities a role in the context of oil and gas development. The nuisances of concern would include smoke, flaring, emissions, odours, and noise. ${ }^{175}$ Although case law can provide some guidance for defining a "nuisance," the lack of definition in the MGA means that municipalities can determine what will constitute a nuisance though their nuisance bylaws. ${ }^{176}$ Ultimately, many environmental impacts could fall either within the "health and safety" or "nuisance" head of power.

\section{CASE STUdy: MUNicipal REgUlation WITH RESPECT TO FLARING, NOISE, AND SETBACKS}

In the protocol it asks the oil and gas industry to follow, Strathcona County says that "flaring is not permitted in Strathcona County." 177 It also encourages operators to follow the County's directions on noise reduction, and it refers to the County's land use bylaw for required setbacks from pipelines. ${ }^{178}$ At a theoretical level, it is possible that such matters as flaring, ${ }^{179}$ noise, and setbacks ${ }^{180}$ in the oil and gas context could fall within either the bylawmaking powers granted to municipalities in Part 2 or Part 17 of the MGA. ${ }^{181}$ Would such bylaws be intra vires the municipality in the face of provincial rules and regulations that cover such matters? ${ }^{182}$

Following Spraytech, the Supreme Court of Canada elaborated upon the appropriate test for determining whether there is inconsistency or conflict between two enactments covering the same subject matter in a 2005 case. ${ }^{183}$ In Rothmans, Benson \& Hedges Inc. v. Saskatchewan, the Court held that impossibility of dual compliance, although a starting point, is not the "sole mark of inconsistency." 184 In addition, an enactment that "displaces or frustrates" the legislative purpose of the higher-level legislator is inconsistent and thereby ultra vires. ${ }^{185}$ Thus, if a municipal bylaw frustrates the legislative purpose of a provincial statute or regulation, the municipal bylaw will be struck down. In Rothmans, because the federal and provincial laws at issue were enacted for "the same health-related purposes,"186 the Court held that the provincial law did not frustrate the purpose of the federal law. Further,

Recently, the Supreme Court of Canada upheld the City of Montreal's power to regulate noise through a nuisance bylaw: Montreal (City of ) v. 2952-1366 Quebec, 2005 SCC 62, [2005] 3 S.C.R. 141.

Mallett, supra note 171 at 5-6. Such a definition would of course have to accord with municipal purposes.

Strathcona Protocol, supra note 11 at 4.

Ibid. at 6-7. Yet, Strathcona County's website notes that it does not have "direct authority" in energy development. It was this belief that led the County to back away from enacting the protocol in bylaw form: see "County, EUB At Odds Over Regulation Change," online: The Land Advocate <http://web. archive.org/web/20050208030518/www.landadvocate.org>.

Flaring refers to the practice of burning off natural gas and other substances during the oil and gas extraction process.

A setback is the distance that must be maintained between an oil and gas facility and another development.

For example, a development permit could stipulate the noise abatement measures that must be adopted. As noted earlier, if conditions are not specified in project approvals, the general rules and regulations for flaring, noise, and setbacks would apply. See e.g. ERCB, Directive 038: Noise Control (Calgary, ERCB, 2007); ERCB, Directive 060: Upstream Petroleum Industry Flaring, Incinerating, and Venting (Calgary: ERCB, 2006); ERCB, Directive 026: Setback Requirements for Oil Effluent Pipelines (Calgary: ERCB, 2005). For our purposes, it is assumed that relevant ERCB rules and guidelines have regulatory status.

2005 SCC 13, [2005] 1 S.C.R. 188 [Rothmans].

Ibid. at para. 12 .

Ibid.

Ibid. at para. 26. 
since it was possible to comply with both laws (because the provincial legislation simply prohibited what Parliament had opted not to prohibit), both laws were allowed to stand. ${ }^{187}$

Post-Rothmans, a court must ask itself two questions in any case of a dispute between the validity of a municipal bylaw and a provincial enactment covering the same subject matter. These are: (1) can a person simultaneously comply with the two enactments?; and (2) does the municipal bylaw frustrate the purpose of the provincial legislation or regulation? ${ }^{188}$ With its language of "inconsistency," s. 13 of the MGA points to this type of analysis. Nothing in the provision suggests the need for a different test. ${ }^{189}$

There is one important caveat on this two-step test, however. In Spraytech, the Supreme Court of Canada noted that the impossibility of dual compliance test would not apply where the relevant provincial legislation specified a different test. ${ }^{190}$ The case of Peacock v. Norfolk (County of $)^{191}$ is an example. There, a proposed expansion of a hog operation had complied with provincial setback requirements and had received provincial approval. Subsequently, the County passed a bylaw prohibiting the siting of intensive livestock operations within certain sensitive areas. The County said that both the provincial regulation and bylaw had to be complied with, and the bylaw prohibited the proposed expansion. The operators argued that the regulation prevailed over the bylaw because a provision in the relevant provincial legislation said that "[a] regulation supersedes a by-law of a municipality or a provision in that by-law if the by-law or provision addresses the same subject-matter as the regulation." ${ }^{\prime 192}$ The provision further stated that where this was the case, the municipal bylaw was "inoperative while the regulation [was] in force." ${ }^{, 193}$ In finding for the operators, the majority of the Court held that this legislative provision specified a different test than the test set out in Spraytech and Rothmans. The provision evidenced an intention to displace the impossibility of dual compliance test. In the result, because the bylaw addressed the same subject matter as the regulation, the bylaw was inoperative.

Based on this case law, in the event a dispute arose as to the validity of a municipal bylaw passed in relation to flaring, noise, or setbacks in the context of oil and gas development, a three-step analysis would be required. The first question would be whether the relevant provincial legislation specifies a different test than that set out in Spraytech and Rothmans. If the answer is yes, then that specifically legislated test would apply to determine if a conflict exists and the bylaw is invalid. If the answer is no, the second question would be whether it is impossible to comply with both the municipal bylaw and the provincial regulation. If it is impossible to do so, then the municipal bylaw would be invalid. If it is possible, however, then the next question would be whether the existence of the bylaw displaces or frustrates the legislative purpose of the provincial enactment. If it does, the bylaw is invalid. If it does not, the bylaw is valid.

According to the Court, if Parliament had intended to make its own regulations the only applicable ones, it should have used "very clear statutory language to that effect": ibid. at para. 21. See Croplife, supra note 25, for a summary of the law post-Spraytech and post-Rothmans.

In Croplife, ibid., the Ontario Court of Appeal considered an equivalent provision to s. 13 of the MGA and noted that the parties had conceded that the provision represented a codification of the "impossibility of dual compliance" test articulated in Spraytech and elaborated upon in Rothmans.

Spraytech, supra note 5 at para. 36.

(2006), 81 O.R. (3d) 530 (C.A.).

Nutrient Management Act, 2002, S.O. 2002, c. 4, s. 61(1).

Ibid., s. 61(2). 


\section{REgUlation PURSUANT TO PART 17 OF THE $M G A$}

As noted, a municipality could, in theory, deal with such matters as flaring, noise, and setbacks through development permits issued pursuant to Part 17 of the MGA. But we know that s. 618 of the MGA exempts oil and gas wells, batteries, and pipelines from the application of Part 17 of the MGA. This likely amounts to a specifically legislated test as discussed in Peacock. Section 618 of the Act says that Part 17 municipal plans and land use bylaws do not apply at all to such facilities. The clear intention of s. 618 is that provincial laws and regulations will be the only ones that apply. Consequently, any attempt by a municipality to regulate flaring, noise, and setbacks through a bylaw passed under Part 17 would be ineffective with respect to oil and gas wells, batteries, and pipelines.

Similarly, if a bylaw were passed under Part 17 that covered flaring, noise, or setback requirements for other oil and gas facilities not exempted by s. 618, it is arguable that s. 619 of the MGA also amounts to a specifically legislated test for resolving conflicts between the bylaw and provincial legislation. As noted, s. 619 says that any approval by the ERCB prevails over any municipal plan or bylaw in the case of oil and gas facilities not covered by s. 618. Consequently, where flaring, noise, or setbacks are dealt with by the ERCB in its project approvals, a municipality could not impose its own requirements. Where, however, such a matter has not been dealt with by the Board, a municipality could, as noted above, impose its own requirements with respect to the details of how a development will proceed.

It is with respect to those detailed matters that a determination of whether a municipal bylaw conflicts with a provincial regulation may be required. For example, assuming the ERCB has not dealt with noise in an approval for a processing plant but the municipality has attached such a condition to the development permit for the processing plant, what would be the result if the municipality's requirements were more stringent than those set out in the ERCB's generic rules around noise? Applying the tests from Spraytech and Rothmans, it is likely that if the noise requirements were more stringent than the provincial ones, the municipal bylaw should be allowed to coexist with the provincial standards. It would be possible to comply with both the provincial standards and the municipal ones. Moreover, if both were passed with the purpose of minimizing impacts to neighbouring properties, it is doubtful that the municipal requirements would be seen as frustrating the provincial requirements.

Similarly, municipalities are likely entitled to augment the setbacks required from such facilities in their development permits unless the ERCB has dealt with setbacks when approving the facility. Where the Board has not dealt with setbacks and a sour gas facility (for example, a sour gas plant) is involved, the Board's general setback rules would apply unless the municipality has its own requirements. ${ }^{194}$ On several occasions, the Board has noted that its setback requirements are minimums only, which may be increased by applications relating to land close to such facilities to the Board for a recommendation on the minimum setback required and the municipality must impose at least the minimum. Section 10(2) of the SDR sets out the provincial minimums for setbacks from non-sour oil and gas wells. 
municipalities. ${ }^{195}$ Strathcona County has, for example, increased the Board's setback requirements in the case of oil and gas pipelines through its land use bylaw. ${ }^{196}$ The City of Calgary's municipal development plan also contemplates the adoption of setback distances greater than provincial minimums to address nuisance impacts such as noise, odours, and flaring. Increases have been required in several northeast Calgary communities home to sour gas development. ${ }^{197}$ Applying the Spraytech and Rothmans tests it is unlikely that such increases, undertaken pursuant to Part 17 municipal planning and development powers, would be held to be invalid. Any decrease in provincial setback requirements set by the ERCB would not, however, pass the applicable tests. ${ }^{198}$

\section{REGULATION PURSUANT TO PART 2 OF THE $M G A$}

What if, instead of a bylaw passed under Part 17, a municipality passed a bylaw under Part 2 of the MGA that had the effect of regulating flaring, noise, or setbacks in the context of oil and gas operations? Let us assume, for example, that a company has obtained a licence from the ERCB to drill an oil or gas well and the licence stipulates that the company must reduce noise from its operations to a specified decibel level. But let us also assume that the municipality has, pursuant to Part 2 of the $M G A$, passed a noise bylaw of general application to protect the health and safety of its residents or to deal with nuisances. The municipal bylaw is more restrictive than the conditions attached to the well licence. Would the company be bound by the municipal bylaw?

With respect to bylaws passed under Part 2 of the MGA, there are no specifically legislated tests such as ss. 618 and 619 in Part 17. The only test specified for resolving a potential conflict between a municipal bylaw and a provincial enactment is s. 13, which, for reasons noted above, points to the application of the Spraytech and Rothmans tests. An unresolved issue arises, however, in regard to the application of s. 10(2) of the MGA. Section 10(2) states that if a bylaw could be passed under Part 2 and also under a "specific bylaw passing power" (defined as a "municipality's power or duty to pass a bylaw that is set out in an enactment other than this [Part]"), the bylaw passed under this Part is "subject to any conditions contained in the specific bylaw passing power." 199 This provision ensures that where the spheres of power in Part 2 overlap with any specific power elsewhere in the MGA, the restrictions in the specific power will be respected. ${ }^{200}$

Does this mean that the exemption for wells, facilities, and pipelines in s. 618 and the priority for ERCB approvals in s. 619 also apply with respect to any bylaws passed under Part 2 of the MGA that might apply to oil and gas activities? Although the matter is not free from doubt, arguably it would depend on the nature of the particular bylaw in question. For example, if a municipality passed a bylaw under Part 2 stating that all oil and gas wells require, for health and safety reasons, a development permit or cannot be located in certain

See e.g. Dynegy Canada Energy Inc.: Application for Pipeline Licence Amendments - Okotoks Field, EUB Decision 2000-20 (31 March 2000); EUB, General Bulletin 99-4, “'Land Development Information Package’ Introducing a New Service” (12 March 1999).

Strathcona County, Bylaw No. 8-2001, Land Use Bylaw (10 July 2001), s. 6.7.

See e.g. Brown, supra note 6.

It would also violate the SDR, supra note 194

MGA, supra note 13, ss. 10(1)-(2).

Croplife, supra note 25 at para. 48. 
areas, this would be an inappropriate use of the Part 2 powers. Such matters are more properly land use planning matters that should be dealt with pursuant to the planning and development powers in Part 17. In the result, the restrictions in Part 17 would apply.

On the other hand, if the bylaw in question is, for example, a general noise bylaw or a bylaw dealing with the release of toxic substances into the atmosphere, then it might be more difficult to argue that s. 10(2) applies and the bylaw is of no effect. This is so because Part 17 does not empower municipalities to pass generally applicable noise bylaws or bylaws in relation to releases of toxic substances. Part 17 allows for bylaws in relation to land use planning. Consequently, because there is no specific bylaw-passing power involved in passing the noise or toxic substances bylaw, s. 10(2) would not apply. In short, this would not be a situation of a municipality using a general bylaw-making power to circumvent restrictions on the ability to use a specific bylaw-making power. Rather, this would be a situation where there was no specific bylaw-making power.

Where s. 10(2) does not apply, any consideration of the validity of such a general noise or toxic substances bylaw would be subject to the Spraytech and Rothman tests. First, it would have to be asked whether the bylaw could be complied with alongside any provincial regulation on the same subject matter. Second, it would have to be asked whether the operation of the bylaw displaces or frustrates the intent or purpose of the provincial enactment. If not, they could both be valid.

In this way, it may be possible for municipalities to regulate some, although certainly not all, aspects of oil and gas development. This may be so even in the case of wells, pipelines, and batteries that are expressly exempted from municipal planning and development powers. ${ }^{201}$ The key, of course, will be ensuring that the purpose of any bylaw falls squarely within a valid municipal purpose in relation to the protection of the health and safety of the municipality's residents, or in relation to nuisances. ${ }^{202}$

\section{CONCLusion}

This article has reviewed Alberta's approach to local governance in oil and gas development. Although a level of government with affected legislated mandates and legitimate interests in oil and gas development, municipalities are granted a limited to no direct role in the setting of energy and land use policy for the province. This is also the case with respect to decision-making around the disposition of provincial oil and gas resources and surface access to public lands. There are no legal requirements to consult with, or even notify, municipalities when such decisions are made, thereby reducing the ability of local governments to influence decision-making and to plan and prepare for the impacts from ensuing development.

With respect to the ERCB project approval stage, the requirement that companies notify and consult with municipalities presents an important opportunity that local governments

\footnotetext{
201 If the legislature meant to exclude entirely oil and gas facilities from the application of Part 2 of the MGA, supra note 13 , it could have said so expressly.

202 Municipal bylaws must also not be prohibitory and discriminatory unless the enabling legislation so
} authorizes: see Spraytech, supra note 5. 
should take advantage of to attempt to have their concerns addressed. Where consensus is not possible, however, municipalities may or may not obtain standing to participate fully in a hearing before the ERCB. This is so despite the fact that the Board has, on numerous occasions, noted that it benefits greatly from information supplied by municipalities in making its public interest determinations. As well, municipalities face a significant barrier to meaningful participation given that they are unlikely to be awarded any costs by the Board. Ultimately, Alberta's approach is to treat municipalities as simply another intervener before the Board with no greater role to play than any other.

Alberta legislation also significantly restricts the ability of municipalities to regulate directly in the context of oil and gas development. Municipalities' land use planning and development powers do not apply to the majority of oil and gas developments (such as wells, batteries, and pipelines) and apply with respect to other facilities (for example, processing plants) only to the extent that the ERCB has not dealt with a particular matter in its approval. Nonetheless, this article has exposed the possibility, albeit untested in the courts to date, that municipalities may have some important powers through the general bylaw-making powers granted by the $M G A$ in the context of oil and gas development.

The goal of this article was to expose and clarify Alberta's approach to local governance in oil and gas development. The next question, of course, is whether this approach remains (if it ever was) appropriate and adequate in the current context. Although this article does not delve into the question of whether an appropriate balance has been struck between centralized and decentralized decision-making, it is hoped that this article will provide a first step towards such a discussion. Given the increasing pressures on municipalities in the oil and gas context, there is a need for open and informed dialogue about the right balance between local elected governments and the provincial one. 